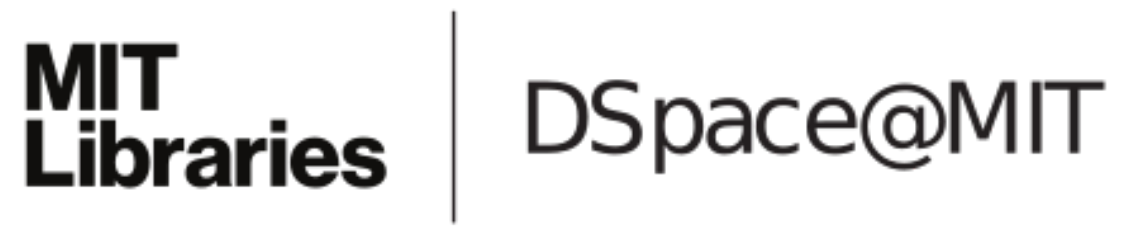

MIT Open Access Articles

Trade Credit and Industry Dynamics: Evidence from Trucking Firms

The MIT Faculty has made this article openly available. Please share how this access benefits you. Your story matters.

Citation: BARROT, JEAN-NOËL. “Trade Credit and Industry Dynamics: Evidence from Trucking Firms." The Journal of Finance 71, no. 5 (September 2016): 1975-2016.

As Published: http://dx.doi.org/10.1111/jofi.12371

Publisher: Wiley Blackwell

Persistent URL: http://hdl.handle.net/1721.1/108627

Version: Original manuscript: author's manuscript prior to formal peer review

Terms of use: Creative Commons Attribution-Noncommercial-Share Alike 


\title{
Trade Credit and Industry Dynamics: Evidence from Trucking Firms
}

\author{
JEAN-NOEL BARROT*
}

\author{
Journal of Finance forthcoming
}

\begin{abstract}
Long payment terms are a strong impediment to the entry and survival of liquidity constrained firms. To test this idea and its implications, I consider the effect of a reform restricting the trade credit supply of French trucking firms. In a difference-in-differences setting, I find that trucking firms' corporate default probability drops by one-fourth following the restriction. The effect is persistent, concentrated among liquidity constrained firms, and not offset by a drop in profits. The restriction also triggers an increase in the entry of small trucking firms.
\end{abstract}

JEL classification: G32, G33, G34, D23

\footnotetext{
*MIT Sloan School of Management. Email: jnbarrot@mit.edu. I am indebted to Antoinette Schoar and David Thesmar for their invaluable guidance and support. I am grateful to Michael Roberts (the editor) as well as two anonymous referees for their suggestions. I thank Francois Derrien, Laurent Fresard, Denis Gromb, Uli Hege, Augustin Landier, Clemens Otto, and Mitchell Petersen for their very helpful comments in the early stages of this project. I am deeply grateful to Claire Lelarge for her insights and assistance with the data. This work also benefited greatly from conversations with Pol Antras, Adrien Auclert, Arnaud Costinot, Fritz Foley, and from the suggestions of seminar participants at the University of Zurich, Wharton, Berkeley Haas, MIT Sloan, Harvard Business School, Yale SOM, Kellogg, Chicago Booth, UNC Kenan-Flager, Fisher College at Ohio State University, Stanford GSB, ESSEC, Cornell, Dartmouth, Duke, Princeton, and Brigham Young University. All remaining errors are my own. I acknowledge support from the AXA Research Fund and the HEC Paris Foundation.
} 
Nonfinancial firms are the main providers of short-term corporate financing to their customers. Accounts payable are three times as large as bank loans and fifteen times as large as commercial paper on the aggregate balance sheet of nonfinancial U.S. businesses. ${ }^{1}$ Moreover, interfirm lending finances a disproportionate share of global trade. ${ }^{2}$ Yet despite its economic significance, trade credit supply has received little attention relative to firms' other financial and real activities, mainly due to the lack of appropriate empirical setting. ${ }^{3}$ In particular, the implications of trade credit provision for firms' corporate liquidity remain poorly understood.

While financially stronger firms can extend trade credit to their customers in the form of long payment terms, their financially weaker rivals might expose themselves to liquidity shocks by doing so. Depending on the intensity of competition, they might not be able to pass this excess liquidity risk onto prices. Long payment terms extended by financially stronger firms might thus prevent their constrained rivals from entering, expanding, and surviving in the industry. The main challenge in identifying this mechanism is that firms compete on many dimensions, and that financially stronger firms might have other comparative advantages over their constrained competitors.

To solve this identification challenge, I exploit a large and exogenous restriction on trade credit supply. I consider a trade credit regulation reform enacted in 2006 that prevented French trucking firms from agreeing with their customers to payment terms in excess of thirty days. This resulted in a significant drop by $15 \%$ in payment terms relative to their pre-reform level. I use a unique dataset covering the universe of all French firms and implement a difference-in-differences (DID) approach to estimate the effect of this trade credit restriction on trucking firms' corporate policies, entry and exit. To do so, I compare the performance of trucking firms to the performance of a control group including all industries that do not use trucking services and have similar customers and suppliers as trucking firms. I confirm that all results are robust to using an alternative control group constructed by matching each trucking firm with a non-trucking firm with similar firm-level characteristics, such as size, profitability, tangibility, leverage, and trade credit supply. ${ }^{4}$

I first ask whether long payment terms impose a liquidity risk on firms, especially financially constrained ones. There is no obvious reason a priori that this should be the case. Accounts receivable are typically considered as liquid assets that should be converted into cash relatively easily in the event of a liquidity shock. In addition, financially constrained firms might extend shorter payment terms than unconstrained ones in order to avoid begin exposed to excessive liquidity risk. 
Instead, I find that the large decrease in accounts receivable is matched by a sizable increase by three percentage points in cash holdings. Most importantly, the probability that a trucking firm files for bankruptcy falls by 60 basis points, a one-fourth drop with respect to the pre-restriction level. The effect is extremely robust across alternative specifications and control groups. It shows no prior trends and remains persistent six years after the trade credit restriction. The effect is concentrated among small, young, cash-poor, highly levered, and low payout firms, which are more likely to be liquidity constrained. Altogether, the results provide consistent evidence that payment terms impose a substantial liquidity risk on financially weaker firms and force them into financial distress more often than if they were paid earlier.

I then check whether financially weaker firms are compensated for the liquidity risk they take by extending trade credit. It may be the case that constrained firms charge higher prices than unconstrained ones to cover their higher liquidity risk. However, I find that the drop in corporate default among constrained firms is not offset by a drop in their earnings. This suggests that, in a competitive market where customers value trade credit, financially constrained firms expose themselves to liquidity risk by extending trade credit, which they are not able to offset with higher prices. Hence, liquidity constrained firms seem to be made relatively better off by the reform. Surprisingly, the restriction of the contract set imposed by this trade credit regulation reform thus leads to a net improvement in the risk-adjusted profits of some market participants.

I also examine whether the liquidity risk associated with trade credit supply acts as a barrier to entry for financially constrained entrepreneurs. Again, there is no obvious reason why this should be the case, given that accounts receivable are relatively liquid assets, and that constrained entrepreneurs could in theory choose to extend shorter payment terms in order to reduce liquidity risk. However, I find that entry goes up in the trucking sector following the trade credit restriction. The increase is concentrated among small businesses, shows no prior trend, and starts to kick in one year after the reform. I ask whether this might be the result of low quality entrepreneurs taking advantage of the lower working capital requirements to enter the sector. I find instead that the productivity of entrants is not lower after the reform than before. This is consistent with the idea that long payment terms extended by financially stronger firms raises the hurdle for firms to enter and survive in the industry. From a broader perspective, these results confirm that trade credit supply acts as a barrier to the entry and survival of liquidity constrained yet productive businesses. 
The findings shed light on the implications of the recent set of reforms undertaken in the U.S. and in the European Union (E.U.) aimed at accelerating payments to small businesses. On September 14, 2011, the U.S. deployed the QuickPay initiative, whereby all federal agencies were obligated to pay their small business contractors within 15 days instead of 30 days. ${ }^{5}$ On March 16, 2013, the E.U. enacted Directive 2011/7/EU preventing suppliers and customers from agreeing to payment terms in excess of 60 days, unless they specify otherwise in writing. ${ }^{6}$ The underlying idea, which is often echoed in the press and in business surveys both in the U.S. and the E.U., is that extending trade credit is costly for small businesses. In particular, policymakers are concerned that long payment terms may impose excess default risk on firms. ${ }^{7}$ The results presented in this paper confirm that financially constrained firms are at a comparative disadvantage in sectors with long payment terms, and that they seem to be made better off by a trade credit restriction. Yet, for any regulation of trade credit to be welfare improving, there would have to be an inefficiently high level of trade credit provision ex-ante, a question that is beyond the scope of this study.

This paper belongs to the growing literature on trade credit, which has received less attention than other sources of corporate financing such as bank debt, despite its economic importance. This stream of research has argued that firms extend financing to their corporate customers because they have an advantage over financiers in dealing with adverse selection (Petersen and Rajan, 1997) or with moral hazard (Burkart and Ellingsen, 2004). ${ }^{8}$ While this paper does not speak to the drivers of trade credit, the reform that I analyze allows for a clean identification of the interaction of trade credit supply with other corporate policies. In particular, the findings highlight that long payment terms absorb enough of firms' liquidity to impact entry and exit. ${ }^{9}$ This mechanism is likely to be amplified during episodes of credit market stress, when external finance becomes scarce, thus amplifying the comparative advantage of financially stronger firms over financially weaker ones through their ability to supply trade credit. ${ }^{10}$

I also build on prior work exploring the interplay between financing frictions and industry dynamics, starting with Telser (1966) and Bolton and Scharfstein (1990), who argue that deeppocketed firms can lower industry profits to accelerate the exit of their financially constrained rivals. My findings indicate that long payment terms are another mechanism through which financial constraints affect firms' entry and exit. Therefore, they complement existing empirical evidence that firms with high levels of leverage or low levels of cash holdings tend to lose market share to 
their rivals (Phillips, 1995; Kovenock and Phillips, 1995, 1997; Campello, 2003; Campello and Fluck, 2006; Fresard, 2010), or to lower quality in order to preserve current cash flows for debt service (Matsa, 2011b). They also relate to prior work showing that incumbents' capital structure influences their rivals' entry (Chevalier, 1995a,b; Khanna and Tice, 2000; Boutin, Cestone, Fumagalli, Pica, and Serrano-Velarde, 2013), and that product market competition influences fims' capital structure decisions (Hoberg, Phillips, and Prabhala, 2014). In a related paper, Zingales (1998) considers the effect of the wave of entry and price liberalization in the U.S. trucking industry and finds that highly levered firms are less likely to invest, and thus more likely to exit. The impact of the trade credit regulation reform also illustrates how capital market imperfections affect the survival of productive firms, but the mechanism relies instead on working capital investment and its effect on short-term corporate liquidity.

At a broad level, the findings presented in this paper contribute to our understanding of the real effect of liquidity constraints. In the presence of adverse selection (e.g., Stiglitz and Weiss (1981)) or moral hazard (e.g., Holmstrom and Tirole (1998)), entrepreneurs may be unable to raise outside finance and may consequently need to forgo some profitable investment opportunities. Financing frictions may affect entrepreneurs' decisions on the intensive margin (whether to invest and expand or not), as well as the extensive margin (whether to enter, and to exit). The first margin has been explored in a number of studies, starting with Fazzari, Hubbard, and Petersen (1988), who find a strong positive relationship between cash flows and investment. ${ }^{11}$ Consistent with the results presented here, Fazzari and Petersen (1993) and Almeida, Campello, and Weisbach (2004) show that constrained firms hold less working capital and hoard less cash than they would in the absence of financial constraints. In contrast, I focus on the effects of liquidity constraints on the extensive margin, that is, on firms' entry and exit, which has received less attention in the literature, with the exception of Evans and Leighton (1989), Evans and Jovanovic (1989), or Holtz-Eakin, Joulfaian, and Rosen (1994). The rich dataset I use combines firm-level data with information on business creations and defaults for the universe of French firms, which enables me to carefully analyze how short-term corporate liquidity impacts the entry and survival of constrained entrepreneurs.

The remainder of the paper is organized as follows. Section I reviews the theory and evidence on trade credit and details the main hypotheses. Section II presents the trade credit regulation reform, which serves as the main source of identification in this paper. Section III details the identification 
strategy. Section IV presents the data. Section V describes the results. I discuss the results in Section VI, and Section VII concludes.

\section{Theoretical Framework}

When there are contractual frictions between customers and external financiers, trade credit may be a crucial source of short-term corporate financing. The ability to extend trade credit might therefore affect firms' entry, expansion, and survival. In what follows, I present the main theories of trade credit provision, which serve as a basis for the hypotheses tested in this paper.

\section{A. Theories of Trade Credit}

Prior work has argued that trade credit is a form of financing used to overcome the impediments customers face in funding their investment opportunities. ${ }^{12}$ Petersen and Rajan (1997) use the National Survey of Small Business Finance (NSSBF) and document that firms with better access to credit from financial institutions in turn offer more trade credit. But why would firms be willing to finance their customer when financial intermediaries would not?

Smith (1987) and Biais and Gollier (1997) argue that firms have an informational advantage over other types of external investors, allowing them to better screen solvent customers. Consistent with this idea, McMillan and Woodruff (1999) find that firms lend to their constrained customers, and that longer trading relationships are associated with more credit provision. In Brennan, Maksimovic, and Zechner (1988), trade credit is used by firms to discriminate between their cash-rich and cash-poor customers when price discrimination is not allowed.

In another vein, Burkart and Ellingsen (2004) hypothesize that it is typically less profitable for an opportunistic borrower to divert inputs than to divert cash, which increases the advantage of firms over banks in lending to their customers. This theory predicts that producers of differentiated goods, which are typically harder to divert, should extend more trade credit. Empirical evidence based on the NSSBF in Giannetti, Burkart, and Ellingsen (2011) confirms that differentiated goods are offered with longer payment terms.

The advantage of trade partners over external financiers may also be nested in the specificity of the supplier-customer relationship. Wilner (2000) argues that firms are more willing than banks to 
grant concessions to customers in debt renegotiation to sustain trade relationships. Cuñat (2007) posits that once relationship-specific investments have been made, customers have weaker incentives to default on their suppliers than on their banks, while suppliers have stronger incentives to lend to customers experiencing financial distress.

Finally, firms could attribute a larger value to the collateral of their financially constrained customers than would external financiers; they might thus be willing to offer credit when banks may not. Consistent with this idea, Longhofer and Santos (2003) and Frank and Maksimovic (2005) relate trade credit provision to firms' advantage in liquidating intermediate goods in case of default by their customers.

The common feature of these theories is that the production process creates a comparative advantage for nonfinancial firms over financial intermediaries in providing short-term corporate financing to their customers. A joint prediction of these theories is that payment terms should be clustered by industry, as they are very much dependent on the respective positions of the firm and its customer in the supply chain. Ng, Smith, and Smith (1999) and, more recently, Costello (2013), provide compelling contract-level evidence that there is indeed significant variation in payment terms across industries, but much less so within industries. Hence, operating in a given industry requires not only the ability to achieve technological and organizational efficiency, but also the capacity to extend trade credit. However, firms may differ in their ability to do so due to heterogeneous exposure to liquidity constraints. ${ }^{13}$

\section{B. Hypotheses}

I borrow from Holmstrom and Tirole (1998) to derive the set of hypotheses tested in this paper. In this setting, entrepreneurs use wealth and external funds to finance the initial fixed cash outlay required to operate in an industry. In the presence of moral hazard, the entrepreneur must be given a minimum share of the claims on the firm's profits in order to produce effort. This prevents some projects with positive net present value from being financed. In particular, a liquidity shock hitting the firm can force it into liquidation even though it has a positive continuation value, because the future income that can be pledged to financiers is too low. Firms hold liquid reserves ex-ante to ensure against this risk. There are three possible outcomes, depending on the entrepreneur's initial wealth. Those with enough initial wealth can raise external funding, hoard the first-best level of 
cash, and always continue a project after a liquidity shock when it is efficient to do so. On the other hand, entrepreneurs with too little initial wealth cannot raise enough finance to pay the cash outlay to enter the market in the first place. Entrepreneurs with intermediate levels of initial wealth can raise funding and enter the industry, but they are terminated when the liquidity shock outsizes what they can pledge to financiers, despite the fact that the net present value of continuation is positive. A natural prediction of this model is that, everything else being equal, a larger cash outlay required to operate in an industry leads to more liquidations of efficient firms, and to less entry of cash-poor entrepreneurs. This model is useful to think about how trade credit supply interacts with financial strength to affect liquidations and business creations, and about how a restriction on payment terms might affect firm dynamics in the trucking industry.

Do long payment terms impose liquidity risk on firms, especially financially constrained ones? There is no obvious reason a priori that this should be the case. In principle, accounts receivable are liquid assets that should be converted into cash relatively easily in the event of a liquidity shock. Firms could sell their accounts receivable to banks or factoring companies in such instances. In the simple model presented above, the ability to liquidate or securitize the initial cash outlay would indeed mitigate the inefficient discontinuation of efficient firms. ${ }^{14}$ Furthermore, trade credit would not force excess liquidation on constrained firms if they could extend shorter payment terms than those extended by unconstrained firms. In the framework of Holmstrom and Tirole (1998), constrained firms can mitigate inefficient liquidation by reducing the size of the initial cash outlay. However, if the demand is very elastic to payment terms, then constrained firms might have to offer long payment terms and bear liquidity risk by doing so. Everything else being equal, following a restriction on payment terms, on average, the probability of financial distress should decrease, and more so for financially weaker firms than for financially stronger ones. ${ }^{15}$

Are financially constrained firms compensated for the liquidity risk they take in extending long payment terms? Constrained firms could trade-off liquidity risk with the level of profits. It could be the case, for instance, that they pass the excess default risk they take onto prices. However, the nature of their competitive landscape might prevent them from doing so. Constrained firms might have to offer the same price and payment terms as unconstrained incumbents. If this is the case, then following a restriction on payment terms, the drop in the liquidity risk of constrained firms should not be offset by a relatively larger reduction in their profits. ${ }^{16}$ Although the trade credit 
reform restricts their ability to freely contract with their customers, it might thus be the case that financially weaker firms end up benefiting from the reform.

Do long payment terms prevent the entry of new businesses? In Holmstrom and Tirole (1998), entrepreneurs need to have enough initial wealth to be able to raise external funding to cover the initial cash outlay required to start their operations. Long payment terms amount to a large cash outlay, and they might thus act as a barrier to entry for entrepreneurs with low initial wealth. If the restriction on payment terms reduces the initial cash outlay without affecting earnings, we might see the entry of constrained entrepreneurs increase in the trucking industry after the reform. ${ }^{17}$

\section{The 2006 Trade Credit Regulation Reform}

\section{A. The Trade Credit Regulation Reform}

The main source of identification in this paper is a trade credit regulation reform that came into effect in France on January 5, 2006. It offers a unique opportunity to study the implications of trade credit supply, to the extent that it had a large, sudden, and direct effect on the balance sheet of the entire population of firms in one specific industry.

\section{[Place Figure I about here]}

This reform restricted the length of contractual payment terms to a maximum of thirty days in transactions involving a seller affiliated to one of six four-digit industries related to road transportation. As displayed in Table I below, nine out of ten firms affected by the reform are trucking firms - the remainder include transportation services firms. In the interest of clarity, I refer to these firms collectively as "treated firms" or "trucking firms" throughout the paper. Following the reform, trucking firms and their customers are both subject to a 75,000 euro fine if they agree to payment terms longer than thirty days. Two mechanisms ensure that the reform is enforced. First, the French competition administration conducts investigations among French firms. Second, firms' statutory accounting auditors must report excess contractual payment terms to the Ministry of Finance, the equivalent of the U.S. Department of Commerce. It is important to emphasize that the reform did not affect the enforcement or penalties associated with late payment, that is, to payments occurring beyond the agreed payment term. Instead, the law restricted contractual 
payment terms only.

The impact of the reform on the accounts receivable of trucking firms was dramatic. Figure I presents the mean and confidence interval at the $1 \%$ level of the ratio of receivables over sales in the transportation and logistics sector in France from 1996 to 2011, as reported by the French Central Bank (Banque de France). ${ }^{18}$ The graph highlights that payment terms collapse to a historically low level following the enactment of the reform. Mean receivables over sales drop by 3 percentage points between 2005 and 2007. This amounts to a cut in average payment terms by almost two weeks, or to a $15 \%$ drop with respect to their median level in 2005 , one year before the trade credit restriction. ${ }^{19}$ Although the effect of the reform on payment terms appears to be significant, one concern might be that the reform was not fully enforced. In theory, firms could attempt to contract around the reform. A first possibility would be for the firm to charge a lower penalty rate when the customer pays late. ${ }^{20}$ A second way would be for the firm to delay invoicing. ${ }^{21}$ However, the large drop in accounts receivable and the significant offsetting increase in cash holdings that I document in this paper suggest that the reform was largely enforced. ${ }^{22}$

Why was the 2006 trade credit regulation reform adopted in the first place? The regulation of payment terms had been on the European agenda for a number of years. On June 29, 2000, the European Commission adopted Directive 2000/35/EC designed to prevent late payment practices. This initiative was based on the belief that long payment terms were costly for businesses, especially smaller ones. It created a statutory right to receive interest payments after thirty days following the date of the invoice, unless another payment period was agreed upon in the contract. In July 2011, a Directive 2011/7/EU was adopted to harmonize maximum payment terms at sixty days. ${ }^{23}$ The main motivation for this directive lies in the widely spread view among European policymakers that long payment terms impose excess default risk on small businesses. ${ }^{24}$ The deadline for Member States to transpose this new regulation into their respective national laws was March 16, 2013.

The adoption of a reform specifically targeting French trucking firms is somewhat accidental. The law was part of a legislative package that targeted the safety of French transportation. The trade credit regulation was not part of the initial draft prepared by the government. It was introduced in later rounds of parliamentary discussions, with an amendment submitted when the Act was discussed in the Senate. ${ }^{25}$ This explains why the reform does not seem to have been anticipated in any way. Payment terms were subsequently restricted to forty-five days in the remainder 
of the French economy in 2009. This suggests that the trade credit restriction was going to be implemented anyway, irrespective of the characteristics of the trucking sector.

\section{B. Contemporaneous Legislation}

To ensure that the results presented in this paper are indeed caused by the drop in payment terms, I examine whether other legislation adopted at the same time might be driving the results in one direction or another. First, given that the trade credit reform was part of an Act targeting the safety and development of French transportation, one concern might be that other provisions of the new law might also have an effect on trucking firms. Table CI in the Internet Appendix presents a summary of all the Articles of the Act. While most of these provisions are unlikely to directly affect the trucking sector, the Act introduced a price adjustment mechanism for long-term contract prices, opened rail freight to competition, and created an experimental tax in one of the French regions, which could have affected trucking firms. In the first paragraph of Section D of the Internet Appendix, I describe these provisions in more detail and show that they do not seem to be driving the results.

While the other provisions in the legislative package are unlikely to be driving the results, it is important to also check whether other legislation pertaining to the trucking industry was enacted during the sample period. I searched all European directives adopted between 1995 and 2008 and the acts transposing them into French law, as well as any pieces of legislation including the words "road transportation". The main legislative changes that occurred over this period pertained to the harmonization of labor regulations and toll systems across E.U. Member States. In the second paragraph of Section D of the Internet Appendix, I set out these legislative changes in detail, and present evidence that they do not seem to be affecting the estimates.

Finally, another concern may be that broader reforms adopted in France at the same time as the trade credit regulation reform might affect the results. The fact that the identification strategy relies on a difference-in-differences approach, which controls for economy-wide shocks affecting both treated and control firms, mitigates these concerns. However, if the treatment and control groups are differentially exposed to these reforms, and if the effect of these reforms is large enough, then the results might be biased in one direction or another. In the third paragraph of Section D of the Internet Appendix, I discuss whether the estimates presented in the paper could be affected by the 
introduction in 2006 of an Act affecting immigration law, and an Act affecting bankruptcy law. I find that neither of these pieces of legislation could explain the variation in defaults and entry observed following the trade credit regulation reform.

\section{The Trucking Industry in France}

The French trucking industry is comparable to its U.S. counterpart ${ }^{26}$ and represents a substantial share of the French economy. As of 2003, the industry employs approximately 440,000 workers and generates combined sales of approximately 60 billion euros. According to the 2003 input-output table of the French economy, the largest three-digit sector supplying the trucking sector is oil and gas, which represents $22 \%$ of its input. Its main downstream three-digit sector is the wholesale sector, which accounts for $29 \%$ of its aggregate output.

Road transportation is the dominant transportation mode. Table AII in the Internet Appendix presents the share of road transportation out of total transportation in France between 2003 and 2008. It is remarkable that only a small share (about 15\%) of road transportation is internalized. Moreover, this proportion is stable through time, suggesting that the demand for external road transportation services is quite inelastic and did not collapse following the restriction. However, although road transportation is a significant business segment of the economy, it represents only a small share of average production costs. Using the input-output tables of the French economy in 2003, I find that the weighted average share of transportation costs across industries' input is lower than $1 \%$. This mitigates the concern that the regulation might have had large general equilibrium effects in the French economy, which would affect the estimates of its impact on trucking firms.

\section{Identification Strategy}

\section{A. Difference-in-differences Setting}

I analyze the response of trucking firms to the 2006 trade credit regulation in a difference-indifferences (DID) setting. This allows for a clean analysis of the effect of the restriction on payment terms by controlling for any trends that might affect the French economy as a whole. I build the control group conservatively, by including firms that are unlikely to be using trucking services, and that have a similar position in the supply chain, which the literature has found to be an important 
determinant of trade credit supply. To do so, I use the 2003 input-output table of the French economy at the three-digit level and split the sample based on (i) the share of trucking services out of the total input of each sector, (ii) the distance between the vectors of output shares of each sector and the trucking sector, and (iii) the distance between the vectors of input shares of each sector and the trucking sector. I restrict the sample to sectors falling in the first tercile of (i) the share of trucking services, (ii) the distance between vectors of output shares, and (iii) the distance between vectors of output shares.

The control group includes four three-digit industries and a total of twenty-seven four-digit industries. Unsurprisingly, it essentially includes business support services, as evidenced in Table I. From an economic perspective, these sectors are relevant controls for the trucking industry, to the extent that they occupy a similar position in the supply chain, which is likely to drive not only their supply of trade credit prior to the reform, but their investment opportunities as well.

\section{[Place Table I about here]}

Treated and non-treated firms could, however, differ along a number of dimensions, which might be correlated with the outcome variables and bias the estimation in one direction or another. To overcome this issue, I control for firms' initial characteristics, as well as their interaction with a Post dummy. These controls ensure that the results are not driven by the pre-reform differences between treated and non-treated firms. They prevent the estimation from being biased if the treatment and control groups vary in their sensitivity to macroeconomic fluctuations due to heterogeneous distributions of firm characteristics, such as size, profitability, or leverage. I first compare the behavior of treated and control firms in the three years prior (2003 to 2005) and the two or three years following the reform, depending on data availability. I do so by running the following firm-level OLS regression.

$$
Y_{i, t}=\alpha_{1}+\alpha_{2} \text { Post.Treated }{ }_{i}+\alpha_{3} \text { Post. } X_{i}+\eta_{t}+\delta_{i}+\epsilon_{i, t},
$$

where $Y_{i, t}$ is the outcome of interest measured in year $t$ for firm $i$. Post is a dummy equal to one in the years following the reform and zero in the three years prior to the reform. Treated is a dummy indicating whether firm $i$ belongs to the treatment or the control group. $X_{i}$ is a vector of firm-level controls measured in 2003 including the log of assets, the ratios of sales to assets, gross profit to 
assets, fixed assets to assets, and leverage to assets. $\eta_{t}$ and $\delta_{i}$ are respectively year and firm fixed effects, and $\epsilon_{i, t}$ is an error term. $X_{i}$ does not enter separately in the baseline regression because it is absorbed by firm fixed effects. In the analysis of corporate defaults, however, where firm fixed effects are not included, the vector of firm-level controls enters separately in the regression. The Post dummy is never included separately because it is absorbed by year fixed effects. In all specifications, standard errors are clustered at the four-digit sector level (Bertrand, Duflo, and Mullainathan, 2004). The coefficient of interest is $\alpha_{2}$, which measures the change in $Y_{i}$ following the reform for trucking firms, relative to their controls.

I check in Section B of the Internet Appendix that all results are robust to substituting the interaction of controls with the Post dummy in the OLS regression for a matching procedure. To do so, I match each trucking firm in the treatment group with a non-treated firm belonging to the same quartile of assets, ratio of sales to assets, gross profits to assets, debt to assets, receivables over sales, and fixed assets to assets in 2003. When a treated firm has several matches, I keep the non-treated firm with the smallest Euclidean distance in terms of all matching variables after standardizing them. Again, this procedure ensures that the results are not driven by pre-reform differences between treated and control firms along observable dimensions.

I then analyze how the impact of the reform varies with the intensity of financing frictions. I follow Fazzari et al. (1988), Almeida et al. (2004), Hadlock and Pierce (2010), and others, and use firms' size, age, ratio of cash holdings to assets, ratio of leverage to assets, and payout policy to measure financial strength. I first rank firms based on size in 2003, three years prior to the reform. I ascribe firms to the financially stronger group if the book value of their assets lies in the top half of the sample distribution in 2003. The intuition of using size is that small firms are more vulnerable to capital market imperfections (Almeida et al., 2004). Moreover, Hadlock and Pierce (2010) show that size is the strongest predictor of financial constraints, along with age. Hence, I also rank firms based on their age in 2003. Firms are classified as financially stronger if they fall within the top half of the sample distribution of age in 2003. Leverage and cash holdings have been associated with financial strength in a number of studies, including Chevalier (1995a,b), and Fresard (2010). Hence, I split the sample based on the ratio of cash holdings to assets (net of accounts receivable) and allocate firms to the financially stronger group if they lie in the top half of the sample distribution in 2003. Conversely, I split the sample based on the ratio of total leverage 
to assets and allocate firms to the financially stronger group if they lie in the bottom half of the sample distribution in 2003. Finally, I follow Fazzari et al. (1988) and measure financial strength based on firms' payout policy. Firms are allocated to the financially stronger group if the average ratio lies in the top half of the sample distribution. All proxies are arguably imperfect measures of financial constraints. However, to the extent that I find consistent results across these measures, they are useful in pinning down how the effect of the reform varies in relation to the intensity of financing frictions.

I run the same OLS regression as above, augmented with the interaction of the Post.Treated variable with $F C_{i}$ (financially constrained) and $N o n F C_{i}$ (non financially constrained), two dummies which capture the intensity of financial constraints based alternatively on firm size, age, payout policy, cash holdings, and leverage:

$Y_{i, t}=\beta_{1}+\beta_{2}$ Post.Treated ${ }_{i}$ FC $_{i}+\beta_{3}$ Post.Treated. NonFC $C_{i}+\beta_{4}$ Post.FC $C_{i}+\beta_{5}$ Post. $X_{i}+\eta_{t}+\delta_{i}+\epsilon_{i, t}$,

In this specification, $\beta_{2}$ measures the change in $Y_{i}$ following the reform for financially weaker trucking firms relative to their financially weaker controls. $\beta_{3}$ measures the change in $Y_{i}$ following the reform for financially stronger trucking firms relative to their financially stronger controls.

\section{B. Internal Validity}

A crucial assumption for the DID estimation to be valid is that the treatment and control groups should follow parallel trends in the absence of a restriction on payment terms. Since the reform occurs at the industry level, the parallel trends assumption might not hold if there are diverging latent trends between treatment and controls. In Figure II, I plot the average cumulative change in receivables over sales of treated and control firms from 2003 to 2007, along with 1\% confidence intervals. The graph shows that the two groups follow parallel trends prior to the reform. Receivables of treated firms then drop sharply following the introduction of the law. This confirms that control firms are similar to treatment firms in terms of trade credit provision prior to the reform.

\section{[Place Figure II about here]}


A related concern is that the decline in corporate defaults and the increase in entry were caused by some trends specific to the trucking sector, rather than by the trade credit regulation itself. The fact that the control group includes sectors that have similar suppliers and customers as trucking firms should mitigate this concern. However, suppose that there was a spike in corporate defaults in the trucking industry in the years prior to the reform. Policies such as the trade credit regulation reform could have been implemented in response to this situation. The subsequent decline in corporate default could result from the reversion of default rates to their pre-spike level, rather than being caused by the trade credit reform itself. To check whether this is the case, I inspect the level of corporate default rates in the treatment and control groups in the six years prior to the restriction. I construct corporate default rates as the ratio of corporate defaults in the treated and control groups to the number of firms filing tax forms in the previous year. The results presented in Figure AI in the Internet Appendix indicate that there is no spike in default rates that would cause a reversion around the timing of the reform. Instead, the change in default rates seems to occur precisely after the adoption of the law. Furthermore, in the analyses presented in Section V, I split the Post dummy into year dummies, and show that the effect of the reform on defaults and entry only kicks in following the restriction.

Another concern might be that the reform was passed at a time when investment opportunities in the trucking sector improved relative to the treatment group. Reassuringly, Table AIII in the Internet Appendix shows that the total output of the trucking sector does not change compared with the output of the control industries around the restriction. When such a reform is being passed, one might also be concerned that it is more likely to be lobbied for by large firms with better political connections, which can ensure that the reform is adopted precisely at the time when they expect to gain the most. In this case, the reform helped small firms, which are arguably the ones with the fewest connections. For the reform to be endogenous to the results, it would thus have to be the case that there would be better opportunities for financially constrained than for unconstrained firms, and that perhaps because constrained trucking firms managed to lobby harder, the reform was implemented right at that time. However, I am confident that this is not driving the results since the reform was extended to the rest of the economy two years later. ${ }^{27}$

Finally, although firms in the control groups have similar customers and suppliers as trucking firms, and are therefore likely to be similarly exposed to macroeconomic shocks, it could still be the 
case that default and entry in the two groups have a differential sensitivity to some macroeconomic variables, such as GDP growth. Table AI in the Internet Appendix presents key macroeconomic indicators for the French economy over the sample period. Real GDP growth is slightly higher on average in the pre- than in the post-period (1.74\% versus $1.64 \%)$. If the trucking sector had a lower sensitivity to the business cycle, this might explain why corporate default goes down, and why entry goes up in the post-period. To check whether this is the case, I estimate the beta of treated and control firms' cash-flows with respect to GDP, using all available data from 1995 to 2005, as the covariance between the change in EBITDA scaled by lagged assets (all variables are deflated and are therefore expressed in real terms), and real GDP growth, divided by the variance of real GDP growth. ${ }^{28}$ Table AV in the Internet Appendix shows that conditional on other firm characteristics, the beta of firms cash-flows with respect to GDP is slightly larger in the treatment than in the control group, but not significantly so. If anything, given that real GDP growth is slightly lower in the post-period, this should bias the results against finding a drop in defaults and an increase in entry. Furthermore, in some of the tests described in Section V, I interact the treatment dummy with GDP growth and changes in fuel costs and find that this does not affect the main coefficient. Overall, the evidence indicates that the exposure of treated and control firms to macroeconomic shocks is not significantly different, and unlikely to bias the estimates.

\section{Data}

\section{A. Firm Characteristics}

I use accounting data extracted from tax files used by the French Ministry of Finance for corporate tax collection purposes, available up to 2007. This source is an extended version of the dataset used in various studies, including Bertrand, Schoar, and Thesmar (2007). It includes the

balance sheets and profit and loss statements of the universe of incorporated French firms. ${ }^{29}$ The data is not publicly available, but is available for academic research through a procedure similar to accessing Census data in the U.S. Relative to the NSSBF, this data source has the advantage of tracking firms through time and of being free from the misreporting concerns usually associated with survey-based data. Relative to Compustat, the dataset has the advantage of covering the population of firms, which allows for precise analysis of entry and exit. I track firms through time 
with their unique identifying number ascribed by the French Statistics Office (INSEE). I allocate firms to the treatment and control groups using their historical four-digit industry classification code, which is very similar to the SIC coding system in the U.S. Codes are ascribed to each firm by the French Statistics Office itself. I exclude the financial and real estate sectors, which have different accounting standards. I also exclude utilities, non-profit, and regulated sectors, as they have specific default procedures. ${ }^{30}$

\section{B. Measuring Trade Credit Supply}

The trade credit regulation reform of 2006 applies to contractual payment terms. Information at the contract level is unavailable. Hence, I proxy for payment terms with the ratio of accounts receivable on firms' balance sheets at the end of their fiscal year to the their annual sales.

While this measure has been widely used in the literature as a proxy for trade credit provision, it is only a rough proxy for actual payment terms. Importantly, this ratio mechanically overestimates average payment terms during periods of growth and underestimates them during downturns. If sales increase in the second half of the year, the ratio of end-of-year accounts receivable to total sales overestimates the true average payment term. This explains why the accounting ratio of receivables to sales tends to increase in boom years and decrease in bust years. ${ }^{31}$ This makes it all the more important that the control group should include firms with similar patterns to trucking firms, and that all regressions should include year fixed effects.

Second, accounts receivable on the balance sheet mechanically overestimate the true level of contractual payment terms. Firms record sales in their books at the time when the property of supplied goods changes hands, but they often invoice their customers afterwards. Since payment terms are often based on the time of invoicing, the time between the actual sale and payment is usually longer than the true contractual payment term. Suppose, for instance, that a firm organizes all its invoicing at the end of each month and offers thirty days to all its customers. If the firm produces and sells continuously during the month, then the average effective time between a sale and a payment (thirty days after invoicing) is forty-five days. In this case, the ratio of accounts receivable to sales observed on the books implies an average payment term of forty-five days.

To prevent outliers from affecting the results, I filter out observations with a fiscal year of more or less than twelve months, or with a ratio of accounts receivable to sales larger than one, and I 
winzorise all ratios at the $1 \%$ level.

\section{Corporate Defaults and Entry}

The main outcome variables in this paper are corporate defaults and business creations. ${ }^{32}$ For the analysis of corporate defaults, I use a file produced by the French Statistics Office that reports an exhaustive list of all corporate default initiations along with the unique identifying number of the corresponding company between 2003 and 2008. The date of the initiation corresponds to the time when the relevant court opens the bankruptcy procedure, which takes place soon after the top management has filed a report stating that the firm cannot cover its short-term liabilities. This data is uniquely suited to test the hypotheses developed in Section I. Its main limitation is that it does not specify whether the firm ends up being liquidated or reorganized following the initiation of the bankruptcy procedure. I construct a dummy for liquidations that takes the value of one in the year of the initiation of a corporate default procedure if the firm is administratively terminated in the same or the following year, a detail that appears in the tax files. Unfortunately, this proxy may also capture business sales that are not actual liquidations, but that result in a change in the tax identifier. As such, it may overestimate the number of "pure" liquidation outcomes.

I also measure the probability that trucking firms miss a payment to their own suppliers. I obtain an exhaustive list of payment defaults from the CIPE ("Fichier Central des Incidents de Payment sur Effets"), a dataset maintained by Banque de France that contains information on all firms' payment defaults related to trade bills (with the exception of checks) from 2003 to $2008 .{ }^{33}$ When a firm misses a payment on a trade bill, its bank is required by law to notify the default to Banque de France within four working days. The great feature of this data is that it includes the reason for the payment default, such as a disagreement on the delivery of the goods, the illiquidity of the firm, or the insolvency of the firm once it has filed for bankruptcy. For the purpose of this paper, I focus on payment defaults due to the illiquidity of the firm. These payment defaults are recorded whenever there are insufficient funds in the firm's account to cover the payment, prior to the initiation of any corporate default procedure.

Finally, I obtain from the French Statistics Office the list of all business creations from 1993 to 2008, including the month of creation and an estimation of the number of employees at creation. 


\section{Results}

\section{A. Summary Statistics}

Table II presents descriptive statistics that compare treated and control firms. Panel A shows the summary statistics for the sample of incumbents. Control firms have slightly higher cash holdings, slightly lower fixed assets, and slightly higher gross profit margins than treated firms. Their default probability is also slightly higher than in the treatment group. Even though these differences are economically small, I ensure that they do not drive the results by including a vector of firm-level characteristics interacted with Post in the regressions. Additionally, I present in Section B of the Internet Appendix the summary statistics of the matched control group, which includes the nearest neighbor to each treated firm based on the quantile matching procedure described in Section III. Unsurprisingly, the treated and matched control groups are much closer on all dimensions, as evidenced in Table BI.

\section{[Place Table II about here]}

\section{B. Average Impact of the Trade Credit Restriction}

\section{[Place Table III about here]}

I start with the DID estimation of the payment term restriction on the average trucking firm. Table III presents the effect of the trade credit regulation (2006) on the level of payment terms. Unsurprisingly, treated firms experience a significant drop in receivables by 3.3 percentage points. This amounts to a $15 \%$ drop with respect to the pre-reform level. Adding firm-level controls slightly lowers the coefficient, which remains highly economically and statistically significant. I then split

the Post into year dummies. I find no differential behavior across treated and control firms prior to the reform. This suggests that the parallel trend assumption is satisfied, which is crucial for the validity of the DID estimate. The drop in payment terms starts in the year of the restriction, and is amplified thereafter. The reason why the effect is gradual is that the reform applies only to contracts signed after it was enacted. Table BII in the Internet Appendix shows that the results 
are similar to those obtained using the matched control group, which makes it very unlikely that differences in the characteristics of trucking firms and their controls are driving the results.

\section{[Place Table IV about here]}

I then estimate how the balance sheet of trucking firms reacts to this substantial drop in payment terms. The results presented in Table IV, show a large decrease by 4.4 to 4.6 percentage points in the share of receivables in assets. Most of this decrease is offset by a significant increase in cash holdings by 3.5 percentage points, a $25 \%$ increase with respect to their level prior to the shock. The fact that trucking firms hold less cash than they would if payment terms were shorter is consistent with the prediction of Holmstrom and Tirole (1998) that constrained firms hold lower cash balances than they would if the initial cash outlay was lower. The drop in receivables leads to a modest increase in fixed assets by 0.7 to 0.9 percentage points, as evidenced in Columns 5 and 6 of Table IV.

I also examine whether the reform has an effect on leverage, and in particular on short-term debt. The results presented in Columns 7 and 8 of Table IV show a drop by 0.7 percentage points in the ratio of debt to assets, and the coefficient is marginally significant. To be able to see which component of debt is affected by the change, I use more detailed data on debt structure, available for a subset of firms. I first regress total bank debt scaled by assets on the Post $\times$ Treated dummy as well as year and firm dummies, and initial controls interacted with Post. I then split total bank debt into (i) credit lines and overdrafts, and (ii) total debt minus credit lines and overdrafts. The results are presented in Table AIV in the Internet Appendix. The first two columns show that total debt over assets drops by 0.7 percentage points. Columns 5 and 6 show that the drop is concentrated in credit lines and overdraft facilities, which drop by 0.6 percentage points. Yet, there is no meaningful change in other forms of bank debt, as evidenced in Columns 3 and 4 . This analysis suggests that trucking firms are less reliant on credit lines following the restriction, which is consistent with the finding in Petersen and Rajan (1997) that lines of credit appear to be directly financing accounts receivable.

\section{[Place Table V about here]}

I then turn to the analysis of corporate defaults, the main outcome variable of interest. Table $\mathrm{V}$ presents the DID estimate of the effect of the trade credit regulation (2006) on defaults between 
2003 and 2008. ${ }^{34}$ There is a very strong average effect of the restriction on the probability of default, which decreases by 60 basis points, a one-fourth drop with respect to its average prior to the reform. The coefficients are not affected by the inclusion of a vector of initial controls interacted with the Post dummy. This ensures that this finding is not due to the differences in observable characteristics, such as size, profitability, or leverage, between firms in the treatment and control groups. Columns 2 and 4 indicate that there is no prior trend in the effect, which again confirms that the parallel trend assumption seems to be satisfied. The effect starts in 2006 and is amplified one year after the reform. The fact that the effect becomes gradually stronger is consistent with the results presented in Table III. In Table BIV in the Internet Appendix, I replicate the specifications using the matched control group and find stronger results, which ensures that the baseline findings are not driven by systematic ex-ante firm-level differences between the trucking firms and their controls. ${ }^{35}$

Altogether, the findings suggest that payment terms expose firms to liquidity risk, leading them to experience corporate default more often than they would if they extended less trade credit. I test the robustness of these results to alternative proxies for illiquidity. I start by checking that following the restriction, trucking firms are less likely to default on payments due to their own suppliers. I consider a dummy equal to one if the firm has defaulted on a payment to one of its suppliers, due to a lack of sufficient funds in its bank account, and zero otherwise. While payment defaults do not necessarily imply that the firm will ultimately experience financial distress, corporate default is usually triggered by missed payments to suppliers or to other creditors. The estimates presented in Panel A of Table VI show that the restriction on payment terms strongly reduces the probability that trucking firms miss a payment to their own suppliers. The estimates are insensitive to the inclusion of a vector of initial controls interacted with the Post dummy. The effect is insignificant in the year prior to the reform, thus suggesting that trends in the trucking sectors are not driving this result. The reduction is highly significant in the year of the reform and is amplified thereafter. This confirms that firms are more likely to default on their suppliers when they extend long payment terms to their customers.

\section{[Place Table VI about here]}

The results presented in Table $\mathrm{V}$ may have limited implications for industry dynamics if firms 
are merely reorganized, but keep operating after a corporate default. I check that the restriction leads to fewer firm liquidations by using a dummy equal to one if a corporate default procedure is initiated in that year, and if the firm is administratively terminated in the same or the following year. This proxy might also capture business sales that are not actual liquidations, but that result in a change in the tax identifier. The estimates presented in Panel B of Table VI highlight that the restriction leads to a sharp decrease in liquidations. Again, including a vector of initial controls interacted with the Post dummy does not affect the estimates. The effect starts in the year of the reform and grows afterwards. Subject to the caveat regarding the measurement of liquidation outcomes, the results overall highlight that long payment terms increase the probability of corporate liquidation.

\section{[Place Figure III about here]}

Although the firm-level data do not allow me to assess whether the effect persists beyond three years after the reform, I present in Figure III the evolution of payment terms and bankruptcies in the transportation sector and the business services sector from 2003 to 2011 as disclosed by Banque de France. Panel A presents the cumulative change in receivables over sales, while Panel B presents the cumulative change in the log annual number of bankruptcies. The graphs show that the gap in defaults between the treatment and control groups starts widening only after the restriction. It somewhat shrinks with time, which might be due to the fact that a 45 -day restriction on trade credit across sectors was adopted in 2009, but it remains large and significant in the sixth year following the restriction. This suggests that the reform did not simply delay the exit of inefficient firms, but had a long-lasting effect on the sector-wide probability of financial distress. In addition, the dynamics presented in this graph make it unlikely that the drop in corporate defaults was due to a differential reaction of trucking firms to macroeconomic fluctuations, otherwise the drop would have been reversed sometime after the restriction.

To ensure that differences in the sensitivity of treated and control firms to GDP growth are indeed not driving the results, I augment the baseline specification with the interaction of the Post variable and the beta of the firms' cash-flows with respect to GDP, as well as the beta itself. ${ }^{36}$ If the drop in defaults or the increase in entry are driven by the differential beta of the treated and control group, then this variable should absorb most of the coefficient on the Post $\times$ Treated dummy. The 
results of this experiment are presented in Columns 1 and 2 of Table AVI in the Internet Appendix. The coefficient on this additional variable is insignificant, and the coefficient on the Post $\times$ Treated dummy remains unaffected. This makes it unlikely that systematic differences in the beta of firms' cash-flows with respect to GDP might explain the results. I then go one step further and augment these specifications with the interaction between the treatment dummy and real GDP growth. If the decrease in defaults is due to a differential exposure to GDP growth, then this variable should capture most of the effect of the treatment. Columns 3 and 4 indicate that this variable does not predict defaults, and does not affect the main coefficients. Finally, I also check that the results are not driven by differential exposure of treated and control firms to changes in fuel costs. Annual fuel cost changes are slightly higher in the pre- than in the post-period ( $17 \%$ versus $11 \%$ on average), as evidenced in Table AI in the Internet Appendix. If it takes longer for trucking firms to adjust their prices to variations in fuel costs, then sudden increases in these costs might temporarily reduce their profitability and increase the risk of financial distress. I include the interaction of the treatment dummy with the change in fuel costs in the main specification. I present the results in Columns 5 and 6 of Table AVI. The coefficient on this interaction term is not significantly different from zero and does not affect the coefficient on the Post $\times$ Treated dummy. Hence the drop in defaults cannot be driven by differential exposure of the treated and control groups to GDP growth or variations in fuel costs.

\section{Trade Credit Restriction and Financial Strength}

Next, I measure how the effect of the reform on defaults varies with the intensity of liquidity constraints. As detailed in Section III, I measure financial strength by ranking firms based on asset size, firm age, cash holdings, leverage, and payout ratio in 2003.

If extending long payment terms is indeed very costly for financially constrained firms, we might expect that such firms attempt to manage down their liquidity risk by requiring shorter payment terms, or by selecting quickly paying customers at the margin. Table AX in the Internet Appendix presents the difference in the mean level of receivables over sales across all five measures used in the paper to proxy for the intensity of financial constraints. Along these five dimensions, financially unconstrained firms extend more credit than financially weaker ones, which is consistent with the idea that it is less costly for them to do so. This suggests that constrained firms grant slightly shorter 
payment terms to their customers, or that they collect their receivables more quickly than their unconstrained rivals. However, while these differences are statistically significant, they are small relative to the level of receivables over sales, consistent with the idea that it is hard for constrained firms to deviate much from the payment terms extended by financially stronger incumbents.

\section{[Place Table VII about here]}

Table VII presents the DID estimates of the effect of the trade credit regulation (2006) on defaults between 2003 and 2008 conditional on the five proxies for financial strength. Financially weaker firms experience a drop by 80 to 140 basis points in their default probability. The default probability of financially stronger firms decreases by much less. In fact, low leverage, cash-rich and high payout firms do not experience any decrease in their probability of default. The difference between the coefficient on Post $\times$ Treated $\times F C$ and Post $\times$ Treated $\times$ NonFC is presented at the bottom of the table. It is negative and strongly significant across all proxies for the intensity of financial frictions. This confirms that financially constrained firms expose themselves to higher corporate default risk in order to extend payment terms to their customers.

\section{[Place Table VIII about here]}

\section{[Place Table IX about here]}

I then ask whether financially constrained firms are compensated for the liquidity risk they take in extending trade credit supply. It may be that constrained firms charge higher prices than unconstrained ones to cover their higher liquidity risk. I check whether financially weaker firms experience an offsetting decline in profits following the restriction. I run a similar regression for gross profits scaled by sales (profit margin), and for gross profits scaled by beginning of the year assets (return on assets). I present the results in Table VIII and IX. Profit margins seem to decrease slightly, which is the natural consequence of the fact that prices should go down in the trucking sector due to the lower implicit interest payment on the reduced amount of credit supplied. However, the effect is not statistically significant, and there is no evidence of a differential decline in earnings for financially weaker firms. The findings indicate that while suppliers bear more liquidity risk by extending payment terms, they do not pass this excess risk onto prices. A natural 
interpretation of these results is that the competitive pressure prevents them from doing so. This suggests that the subset of financially constrained firms within the trucking industry might have been made better off by the restriction.

I explore whether the differential drop in default might be explained by a differential change in the nature of the lending activity of constrained and unconstrained trucking firms. First, the larger drop in the defaults of constrained firms might be explained if they experienced the largest reduction in receivables after the restriction. In Figure AII in the Internet Appendix, I plot the evolution of receivables over sales in the years around the reform for constrained and unconstrained firms (solid versus dashed line) in the treatment and control groups (dark versus light line). The five panels show that unconstrained firms typically have larger accounts receivable over sales than constrained ones in both the control and treatment groups. Both constrained and unconstrained treated firms experience a drop in receivables following the restriction, but it is slightly more pronounced for the latter than for the former. These results are confirmed in Table X and imply that the larger drop in the defaults of constrained firms cannot be explained by a larger drop in their receivables.

\section{[Place Table X about here]}

In addition, if the trade credit policy of financially constrained firms was riskier prior to the restriction, and if the reduced maturity of their trade credit loans made them less risky, this might explain why they end up defaulting less often after the reform. I consider accounting allowances for doubtful receivables, which are available for a subset of firms. This balance sheet item represents the amount of receivables that firms expect will not be repaid. Firms have incentives to report doubtful receivables on their books since this is a tax-deductible expense. In Table XI, I show that the share of doubtful receivables did not decrease for financially weaker firms following the restriction, and not differentially so with respect to financially stronger firms. Hence, the large reduction in corporate defaults, and the absence of an offsetting drop in profits, cannot be explained by differential trade credit practices. Therefore, although the trade credit reform restricts their ability to freely contract with their customers, it seems that financially constrained firms benefit from the reform.

\section{[Place Table XI about here]}




\section{Entry in the Trucking Sector}

I then study whether the liquidity risk associated with trade credit supply acts as a barrier to entry for financially constrained entrepreneurs. Given that the large drop in defaults is not offset by a drop in profitability, we might see an increase in the entry of financially constrained firms in the trucking sector, as firms realize that they can sustain the same level of earnings as before with a higher probability of survival.

To check whether this is the case, I compare the number of small and large business creations in the treated and non-treated sectors, defined at the four-digit level. Once again, I restrict the set of controls to sectors not using transportation services and those with similar distributions of upstream suppliers and downstream customers. I run the same regression as in the previous section, at the sector level and at a monthly frequency. There are thirty-three four-digit sectors in the sample, including six treated ones. The dependent variable is the logarithm of one plus the number of new businesses in a given sector in a given month. I first consider all business creations, and then the number of small, medium, and large businesses, respectively defined as businesses with zero, one or two, and more than two employees at the time of creation. While the number of employees at creation is admittedly a crude proxy for the intensity of financing constraints, it is available for each new business creation, which is unfortunately not the case with accounting variables. Initial sector controls are the average of the ratios of sales to assets, gross profit to assets, fixed assets to assets, leverage to assets, and receivables to sales in each sector measured in 2003.

\section{[Place Table XII about here]}

Table XII presents the results of this experiment. The restriction leads to a $14 \%$ increase in new business creations. The effect shows no prior trend, consistent with the assumption that treated and control firms would follow parallel trends in the absence of the reform. The effect kicks in one year after the restriction is implemented. This does not come as a surprise, given that the incorporation of new businesses takes some time. The effect is driven by smaller firms, consistent with the idea that financially weaker entrepreneurs benefit the most from the reform. These findings thus indicate that payment terms act as a barrier to the entry of constrained entrepreneurs.

To ensure that differences in the sensitivity of entry to GDP growth between the treatment and control groups are not driving the results, I augment this specification with (i) the interaction of 
the Post variable and the sector average beta of firms' cash-flows with respect to GDP, ${ }^{37}$ (ii) the interaction between the treatment dummy and real GDP growth, and (iii) the interaction between the treatment dummy and changes in fuel costs. The results presented in Table AVII in the Internet Appendix show that the coefficients on these additional variables are insignificant, and that their inclusion does not affect the coefficient on the Post $\times$ Treated dummy. Hence the increase in entry cannot be driven by differential exposure of the treated and control groups to GDP growth or variations in fuel costs.

The inflow of new entrants might be driven by low quality entrepreneurs attracted to the trucking sector because of the lower working capital requirements. To check whether this is the case, I compare the cohorts of entrants in 2003 to 2004 and 2006 to 2007 in the treated and control groups. I first consider the effect of the restriction on the survival of newly created businesses. In Panel A of Table XIII, I measure the probability of survival in the first three years following creation. I find that the probability that new businesses default within year 2 or 3 decreases substantially, by 1.6 to 1.8 percentage points. To assess the quality of the pool of entrepreneurs entering the trucking sector following the restriction, I then consider some proxies for the productivity of these new businesses in their first or second year of activity whenever the following information is available: the ratio of sales to the number of employees, value added to the number of employees, and gross profit to the number of employees. Results presented in Table XIII indicate that new businesses established following the restriction are not less productive than those that entered before.

[Place Table XIII about here]

\section{Discussion}

\section{A. Impact of the Trade Credit Restriction on Transport Users}

For constrained firms to expose themselves to liquidity risk in order to extend payment terms, it should be the case that their customers rely crucially on supplier financing to fund their operations, and that there are no easy substitutes for trade credit. If there were, financially constrained firms would probably offer much shorter payment terms to manage down their liquidity risk.

I attempt to check whether this is the case. I consider the impact of the trade credit restriction 
on transport users. I use a survey conducted in 2005 by the French Statistics Office on a sample of 4,900 manufacturing firms with more than twenty employees or total sales in excess of five million euros, which reports the total amount of external transportation services purchased by each firm. I compute the intensity of external transportation as the ratio of external transportation services purchased to total purchases in 2005. I then label the top two quintiles of the distribution as Transport users and the bottom two quintiles as Non-transport users. I compare the evolution of payables and inventories for Transport and Non-transport users between 2003 and 2007. I then contrast the impact of the reform on Transport users in the top and bottom half of the distribution of asset size in 2003. The results presented in Table AXI in the Internet Appendix indicate that small transport users experience a decrease by 1.3 percentage points in payables over total purchases. This drop seems to be passed on to their inventories, which decrease by 0.9 percentage points, as a proportion of total purchases. Although these findings should be interpreted with caution, they suggest that some customers rely crucially on trade credit received by trucking firms. Following the restriction, they have to reduce their inventories to offset this cut in external financing. ${ }^{38}$

\section{B. External Validity}

To what extent can the results be extrapolated to other contexts? The trucking industry is competitive, and faces a relatively inelastic demand. If the demand for trucking services was very elastic to payment terms, we might have seen a collapse in the demand for trucking services in the first place. In less competitive industries, individual firms might be able to pass higher liquidity risk onto prices, which would probably weaken the effect of a restriction in payment terms on entry.

Specificities of the French economy might also limit the external validity of the experiment. However, trade credit supply is an important dimension of firms' corporate policies both in France and the rest of the world. In December 2005, immediately before the trade credit reform, accounts receivable represented $9.5 \%$ of the aggregate balance sheet of nonfinancial businesses according to Banque de France, versus $8.6 \%$ of the aggregate balance sheet of nonfinancial businesses in the U.S. according to the Flow of Fund accounts. Moreover, prior work by Blazy, Chopard, and Nigam (2013) shows that even distressed firms carry comparable amount of accounts receivable on their balance sheet in France and in the United Kingdom, a common law country.

I check whether the determinants of trade credit supply are similar in other samples widely 
used in the trade credit literature, such as the NSSBF. In Table AXII in the Internet Appendix, I replicate Table 3 of Petersen and Rajan (1997) on my sample in 2003. The dependent variable is receivables over sales, which I regress on the log of assets, the log of age and its squared value, net profit over sales, a variable equal to sales growth if it is positive and zero otherwise, a variable equal to sales growth if it is negative and zero otherwise, as well as gross margin, and a squared term. I find very similar results as Petersen and Rajan (1997): larger firms extend more trade credit. Older firms also extend more credit to their customers, although the relationship is non linear. Both firms with positive and negative sales growth have larger accounts receivable, while firms making losses extend more credit. Finally, the larger a firm's gross profit margin, the greater its receivables over sales. This analysis suggests that the drivers of trade credit provision in the cross-section of firms are similar in my sample and in the NSSBF.

Finally, if indeed trade credit prevents the entry of financially weaker firms, then it should be the case that sectors with longer payment terms also have lower entry rates. I take advantage of the unique dataset covering the whole population of French firms to check whether this prediction is validated in the data. I compute for each year and four-digit sector the entry rate as the ratio of new business creations to the number of firms filing taxes in the previous year. I then regress entry rates on lagged median sector characteristics, including the ratio of receivables to sales, and present the results in Table AXIII in the Internet Appendix. Consistent with the findings presented in this paper, the entry rate of small businesses is strongly negatively correlated with the level of payment terms. However, the opposite applies to the entry rate of large firms. These findings suggest that the mechanism documented in this paper for the trucking industry can be generalized to the cross-section of sectors.

\section{Conclusion}

This paper asks whether financially stronger firms have a comparative advantage over their constrained rivals through their ability to extend trade credit to their customers. To test this hypothesis and its implications, I consider the response of French trucking firms to a reform restricting their ability to agree with their customers to payment terms in excess of thirty days. The reform triggers an abrupt reduction of payment terms by $15 \%$ in the trucking sector. This causes 
a large drop in corporate defaults, which shows no prior trends, is persistent, and concentrated among financially weaker firms. I do not find any evidence that this large reduction in default risk is offset by a decrease in earnings. Hence, financially weaker firms seem to be better off following the restriction. Consistent with this view, the entry of small businesses increases in the trucking sector following the trade credit restriction; moreover, these new entrants are not less productive. This suggests that long payment terms extended by financially stronger firms raises the cost for financially constrained but productive firms to enter and survive in the industry.

The results shed light on the impact of the reforms currently undertaken in Europe and the U.S. to regulate trade credit and accelerate payments to small businesses. Reducing payment terms seems to facilitate the entry and survival of constrained firms. However, because it restricts the contract set and reduces the supply of trade credit for customers, such a restriction is clearly not Pareto optimal. For such a restriction to be welfare enhancing, there should be an excess demand or supply of trade credit, a question that I leave for future research. 


\section{REFERENCES}

Ai, Chunrong, and Edward C. Norton, 2003, Interaction terms in logit and probit models, Economics Letters 80, 123-129.

Almeida, Heitor, Murillo Campello, and Michael S Weisbach, 2004, The cash flow sensitivity of cash, The Journal of Finance 59, 1777-1804.

Antràs, Pol, and C. Fritz Foley, 2011, Poultry in motion: A study of international trade finance practices, Technical report, NBER Working Paper 17091.

Arrunada, Benito, Manuel Gonzalez-Diaz, and Alberto Fernandez, 2004, Determinants of organizational form: transaction costs and institutions in the european trucking industry, Industrial and Corporate Change 13, 867-882.

Baker, George P., and Thomas N. Hubbard, 2003, Make versus buy in trucking: asset ownership, job design, and information, American Economic Review 93, 551-572.

Baker, George P., and Thomas N. Hubbard, 2004, Contractibility and asset ownership: On-board computers and governance In U.S. trucking, Quarterly Journal of Economics 119, 1443-1479.

Bertrand, Marianne, Esther Duflo, and Sendhil Mullainathan, 2004, How much should we trust differences-in-differences estimates?, Quarterly Journal of Economics 119, 249-275.

Bertrand, Marianne, Antoinette Schoar, and David Thesmar, 2007, Banking deregulation and industry structure: Evidence from the french banking reforms of 1985, Journal of Finance 62, $597-628$.

Biais, Bruno, and Christian Gollier, 1997, Trade credit and credit rationing, Review of Financial Studies 10, 903-937.

Blanchard, Olivier Jean, Florencio Lopez-de Silanes, and Andrei Shleifer, 1994, What do firms do with cash windfalls?, Journal of Financial Economics 36, 337-360.

Blazenko, George W., and Kirk Vandezande, 2003, The product differentiation hypothesis for corporate trade credit, Managerial and Decision Economics 24, 457-469. 
Blazy, Regis, Bertrand Chopard, and Nirjhar Nigam, 2013, Building legal indexes to explain recovery rates: An analysis of the French and English bankruptcy codes, Journal of Banking $\&$ Finance 37, 1936-1959.

Boissay, Frederic, and Reint Gropp, 2013, Payment defaults and interfirm liquidity provision, Review of Finance 17, 1853-1894.

Bolton, Patrick, and David S Scharfstein, 1990, A theory of predation based on agency problems in financial contracting, American Economic Review 80, 93-106.

Boutin, Xavier, Giacinta Cestone, Chiara Fumagalli, Giovanni Pica, and Nicolas Serrano-Velarde, 2013, The deep-pocket effect of internal capital markets, Journal of Financial Economics 109, $122-145$.

Brennan, Michael J., Vojislav Maksimovic, and Josef Zechner, 1988, Vendor financing, Journal of Finance 43, 1127-1141.

Burkart, Mike, and Tore Ellingsen, 2004, In-kind finance: a theory of trade credit, American Economic Review 94, 569-590.

Calomiris, Charles W., Charles P. Himmelberg, and Paul Wachtel, 1995, Commercial paper, corporate finance, and the business cycle: a microeconomic perspective, Carnegie-Rochester Conference Series on Public Policy 42, 203-250.

Campello, Murillo, 2003, Capital structure and product markets interactions: evidence from business cycles, Journal of Financial Economics 68, 353-378.

Campello, Murillo, and Zsuzsanna Fluck, 2006, Product market performance, switching costs, and liquidation values: The real effects of financial leverage, in AFA 2007 Chicago Meetings Paper.

Chevalier, Judith A., 1995a, Capital structure and product-market competition: Empirical evidence from the supermarket industry, American Economic Review 85, 415-435.

Chevalier, Judith A., 1995b, Do lbo supermarkets charge more? an empirical analysis of the effects of lbos on supermarket pricing, Journal of Finance 50, 1095-1112. 
Costello, Anna, 2013, Trade credit policy in long term supply contracts, Technical report, Massachusetts Institute of Technology.

Cuñat, Vicente, 2007, Trade credit: suppliers as debt collectors and insurance providers, Review of Financial Studies 20, 491-527.

Daripa, Arup, and Jeffrey Nilsen, 2011, Ensuring sales: A theory of inter-firm credit, American Economic Journal: Microeconomics 3, 245-279.

Dass, Nishant, Jayant R. Kale, and Vikram Nanda, 2014, Trade credit, relationship-specific investment, and product market power, Review of Finance forthcoming.

Demirgüç-Kunt, Asli, and Vojislav Maksimovic, 2001, Firms as financial intermediaries - evidence from trade credit data, Policy Research Working Paper Series 2696, The World Bank.

Evans, David S., and Boyan Jovanovic, 1989, An estimated model of entrepreneurial choice under liquidity constraints, Journal of Political Economy 97, 808-827.

Evans, David S., and Linda S. Leighton, 1989, Some empirical aspects of entrepreneurship, American Economic Review 79, 519-535.

Faulkender, Michael, and Mitchell A. Petersen, 2012, Investment and capital constraints: Repatriations under the american jobs creation act, Review of Financial Studies 25, 3351-3388.

Fazzari, Steven M., R. Glenn Hubbard, and Bruce C. Petersen, 1988, Financing constraints and corporate investment, Brookings Papers on Economic Activity 141-206.

Fazzari, Steven M., and Bruce C. Petersen, 1993, Working capital and fixed investment: new evidence on financing constraints, The RAND Journal of Economics 24, 328-342.

Fisman, Raymond, and Mayank Raturi, 2004, Does competition encourage credit provision? evidence from african trade credit relationships, The Review of Economics and Statistics 86, 345352.

Frank, Murray Z., and Vojislav Maksimovic, 2005, Trade credit, collateral, and adverse selection, Mimeo, University of Maryland. 
Fresard, Laurent, 2010, Financial strength and product market behavior: The real effects of corporate cash holdings, Journal of Finance 65, 1097-1122.

Garcia-Appendini, Emilia, and Judit Montoriol-Garriga, 2013, Firms as liquidity providers: Evidence from the 20072008 financial crisis, Journal of Financial Economics 109, 272 - 291.

Giannetti, Mariassunta, Mike Burkart, and Tore Ellingsen, 2011, What you sell is what you lend? Explaining trade credit contracts, Review of Financial Studies 24, 1261-1298.

Hadlock, Charles J., and Joshua R. Pierce, 2010, New evidence on measuring financial constraints: Moving beyond the kz index, Review of Financial Studies 23, 1909-1940.

Hoberg, Gerard, Gordon Phillips, and Nagpurnanand Prabhala, 2014, Product market threats, payouts, and financial flexibility, The Journal of Finance 69, 293-324.

Holmstrom, Bengt R., and Jean Tirole, 1998, Private and public supply of liquidity, Journal of Political Economy 106, 1-40.

Holtz-Eakin, Douglas, David Joulfaian, and Harvey S. Rosen, 1994, Sticking it out: entrepreneurial survival and liquidity constraints, Journal of Political Economy 102, 53-75.

Hubbard, Thomas N, 2000, The demand for monitoring technologies: the case of trucking, Quarterly Journal of Economics 115, 533-560.

Hubbard, Thomas N., 2001, Contractual form and market thickness in trucking, The RAND Journal of Economics 32, 369.

Hubbard, Thomas N., 2003, Information, decisions, and productivity: On-board computers and capacity utilization in trucking, American Economic Review 93, 1328-1353.

Khanna, Naveen, and Sheri Tice, 2000, Strategic responses of incumbents to new entry: The effect of ownership structure, capital structure, and focus, Review of Financial Studies 13, 749-79.

Kim, Se-Jik, and Hyun Song Shin, 2012, Sustaining production chains through financial linkages, American Economic Review 102, 402-06.

Klapper, Leora, Luc Laeven, and Raghuram Rajan, 2012, Trade credit contracts, Review of Financial Studies 25, 838-867. 
Kovenock, Dan, and Gordon Phillips, 1995, Capital structure and product-market rivalry: how do we reconcile theory and evidence?, The American Economic Review 403-408.

Kovenock, Dan, and Gordon M Phillips, 1997, Capital structure and product market behavior: An examination of plant exit and investment decisions, Review of Financial Studies 10, 767-803.

Lamont, Owen, 1997, Cash Flow and Investment: Evidence from Internal Capital Markets, The Journal of Finance 52, 83-109.

Longhofer, Stanley D., and Joao Santos, 2003, The paradox of priority, Financial Management 32.

Love, Inessa, Lorenzo A. Preve, and Virginia Sarria-Allende, 2007, Trade credit and bank credit: Evidence from recent financial crises, Journal of Financial Economics 83, 453-469.

Matsa, David A., 2011a, Competition and product quality in the supermarket industry, The Quarterly Journal of Economics 126, 1539-1591.

Matsa, David A., 2011b, Running on empty? financial leverage and product quality in the supermarket industry, American Economic Journal: Microeconomics 3, 137-73.

McMillan, John, and Christopher Woodruff, 1999, Interfirm relationships and informal credit in vietnam, The Quarterly Journal of Economics 114, 1285-1320.

Meltzer, Allan H., 1960, Mercantile credit, monetary policy, and size of firms, The Review of Economics and Statistics 42, pp. 429-437.

Murfin, Justin, and Ken Njoroge, 2014, The implicit costs of trade credit borrowing by large firms, Review of Financial Studies forthcoming.

Nadiri, M. Ishaq, 1969, The determinants of trade credit in the u.s. total manufacturing sector, Econometrica 37, 408-23.

Ng, Chee K., Janet Kiholm Smith, and Richard L. Smith, 1999, Evidence on the determinants of credit terms used in interfirm trade, Journal of Finance 54, 1109-1129.

Nilsen, Jeffrey H, 2002, Trade Credit and the Bank Lending Channel, Journal of Money Credit and Banking 34, 226-253. 
Petersen, Mitchell A., and Raghuram G. Rajan, 1997, Trade credit: theories and evidence, Review of Financial Studies 10, 661-691.

Phillips, Gordon M., 1995, Increased debt and industry product markets an empirical analysis, Journal of Financial Economics 37, 189-238.

Rauh, Joshua D., 2006, Investment and financing constraints: evidence from the funding of corporate pension plans, The Journal of Finance 61, 33-71.

Robb, Alicia, and E.J. Reedy, 2012, An overview of the kauffman firm survey: Results from 2010 business activities, Report, Kauffman Foundation.

Smith, Janet Kiholm, 1987, Trade credit and informational asymmetry, Journal of Finance 42, $863-72$.

Stiglitz, Joseph E., and Andrew Weiss, 1981, Credit rationing in markets with imperfect information, American Economic Review 71, 393-410.

Taketa, Kenshi, and Gregory F. Udell, 2007, Lending channels and financial shocks: The case of small and medium-sized enterprise trade credit and the japanese banking crisis, Monetary and Economic Studies 25, 1-44.

Telser, L. G., 1966, Cutthroat competition and the long purse, Journal of Law and Economics 9, $259-77$.

Van Horen, Neeltje, 2007, Customer market power and the provision of trade credit: evidence from eastern europe and central asia, Policy Research Working Paper Series 4284, The World Bank.

Whited, Toni M., 1992, Debt, liquidity constraints, and corporate investment: evidence from panel data, Journal of Finance 47, 1425-1460.

Wilner, Benjamin S., 2000, The exploitation of relationships in financial distress: the case of trade credit, The Journal of Finance 55, 153-178.

Zingales, Luigi, 1998, Survival of the fittest or the fattest? Exit and financing in the trucking industry, The Journal of Finance 53, 905-938. 


\section{Notes}

${ }^{1}$ As of September 2012, according to the U.S. Flow of Funds Accounts.

${ }^{2}$ Antràs and Foley (2011) analyze the sales of a large U.S.-based producer of frozen and refrigerated food products, exporting its production to 140 countries. They find that accounts receivable support $39.2 \%$ of total sales and $78.2 \%$ of sales to common law countries.

${ }^{3}$ Among notable exceptions are the supplier-customer datasets used in Antràs and Foley (2011) or Klapper, Laeven, and Rajan (2012).

${ }^{4}$ Unless otherwise specified, I use the term "firms" throughout the paper to refer to trucking and control firms that are extending trade credit, and the term "customers" to refer to their customers, who are thus receiving trade credit.

${ }^{5}$ See http://www.whitehouse.gov/blog/2011/09/14/getting-money-small-businesses-faster

${ }^{6}$ See Wall Street Journal, March 13, 2013, "EU targets late payers."

${ }^{7}$ See, Financial Times, March 25, 2010, "Late payments push smaller companies into bankruptcy."; the Kauffman Foundation survey results summarized in Robb and Reedy (2012); or EU Commission MEMO/12/742, October 5, 2012 , "Let's stop business closures caused by late payments."

${ }^{8}$ Recent contributions to the literature on trade credit include Wilner (2000), Demirgüç-Kunt and Maksimovic (2001), Frank and Maksimovic (2005), Cuñat (2007), Giannetti et al. (2011), Antràs and Foley (2011), Dass, Kale, and Nanda (2014), Kim and Shin (2012), Klapper et al. (2012), (Garcia-Appendini and Montoriol-Garriga, 2013), and Murfin and Njoroge (2014). I defer a thorough analysis of this literature to Section I.

${ }^{9}$ The idea that trade credit has implications for firms' product market performance has been explored in studies including Nadiri (1969), Brennan et al. (1988), Blazenko and Vandezande (2003), and Daripa and Nilsen (2011).

${ }^{10}$ There is empirical evidence from prior work consistent with this view including Meltzer (1960), Calomiris, Himmelberg, and Wachtel (1995), Nilsen (2002), Taketa and Udell (2007), or Love, Preve, and Sarria-Allende (2007)

11 Subsequent studies have complemented these findings using exogenous variations in cash flows (Blanchard, Lopez-de Silanes, and Shleifer, 1994; Lamont, 1997; Rauh, 2006; Faulkender and Petersen, 2012) or structural models (Whited, 1992). 
${ }^{12}$ Another, more recent stream in the literature explores the extent to which trade credit might serve as a remedy to contractual frictions between trade partners, see for instance Fisman and Raturi (2004), Van Horen (2007), Dass et al. (2014), or Kim and Shin (2012). These theories mostly apply to environments where the quality of goods or services supplied is hard to verify. Such theories are less likely to be relevant in the context of this paper given that the quality of a transportation service is likely to be revealed quickly following the delivery.

${ }^{13}$ Related to this paper, Murfin and Njoroge (2014) use variations in large retailers' cash management policies to investigate the real impact of those cash management strategies on the (small) suppliers of those firms. They show that constrained suppliers are forced to cut back on investment in new plants and equipment when buyers pay more slowly.

${ }^{14}$ In practice, even when receivables are securitized or factored, the seller virtually always retains a fraction of the default risk. The factoring market was not developed in France during the sample period, with less than $1 \%$ of bank loans on aggregate and less than $0.5 \%$ of bank loans in the trucking sector.

${ }^{15}$ A natural concern is that such a restriction might lead to a collapse in the demand for trucking services if the customers of trucking firms can easily find substitutes for trucking services. The evidence presented in Section II indicates that the demand for trucking services is inelastic and does not collapse following the restriction. Nonetheless, this would make it even harder to find a negative effect of the payment term restriction on corporate defaults.

${ }^{16}$ One would expect that prices might go down slightly for all firms in the trucking sector following the restriction, due to the lower implicit interest payments on the reduced amount of credit supplied. However, if constrained firms were able to pass their default risk onto prices, the drop in prices should be larger for them.

${ }^{17}$ Note that if the restriction led to a collapse in the demand for trucking services, it would make it even harder to observe an effect on entry.

18 These figures are computed by Banque de France using their proprietary database, FIBEN, which includes roughly one-third of the firms of the main sample used in this paper. Banque de France disclose their statistics at the two-digit sector level. The transportation and logistics sector also includes air and waterways transportation. However, the trucking sector accounts for approximately $70 \%$ of firms in this sample. 
${ }^{19}$ Note that the ex-post level of receivables over sales does not reach the equivalent of 30/365 of annual sales. There are mechanical reasons for this, which I discuss in Section IV. Moreover, the reform does not affect contracts signed prior to the reform or contracts signed by trucking firms but unrelated to actual transportation services.

${ }^{20}$ The default penalty rate is the refinancing rate of the European Central Bank (ECB) +7 percentage points. The lowest penalty rate allowed by the law is 1.5 times the legal interest rate set by Banque de France, which was $3.3 \%$ in 2003. If the firm was asking for a larger penalty rate prior to the restriction, it could get around the reform by charging a lower penalty rate for late payment.

${ }^{21}$ The 30-day term is computed from the invoice date. Suppose that a firm invoiced its customer 10 days following delivery prior to the restriction. The firm could decide to send the invoice 20 days following delivery, thereby extending the effective payment term for the customer.

${ }^{22}$ While the law applies to any contract when one of the two parties is French, another concern could be that enforcement might be weaker when one of the parties is a foreign firm. Fortunately, the trucking sector is essentially non-tradable: there are very few imports and exports of trucking services. The results are unchanged when I exclude firms that were exporting prior to the reform and firms located in districts located close to a border (See Table AVIII in the Internet Appendix).

${ }^{23}$ See Financial Times, April 29, 2010, "EU late payment law moves a step closer."

${ }^{24}$ See E.U. Commission MEMO/12/742, October 5, 2012 , "Let's stop business closures caused by late payments."

${ }^{25}$ Amendment number 16, submitted by Senator Charles Revet.

${ }^{26}$ It is, however, less concentrated: while the U.S. trucking industry is constituted of large companies hiring many employee drivers, there are more independent contractors owning and driving their own trucks in France (Arrunada, Gonzalez-Diaz, and Fernandez, 2004). The characteristics of the U.S. trucking industry have been thoroughly described in the work of Baker and Hubbard (2003, 2004) and Hubbard (2000, 2001, 2003), who show that the introduction of on-board computers (OBCs) has two opposite effects on the structure of this industry: OBCs' incentive-improving capabilities leads to larger, more integrated firms, while OBCs' resource-allocation-improving capabilities leads to smaller, less integrated firms.

${ }^{27}$ Anecdotal evidence suggests that the 2006 reform was lobbied for by trucking unions and 
lobbied against by freight transportation user organizations. The main trucking union in France, the FNTR, has approximately 12,500 member firms, mostly small and medium sized businesses. Transport user organizations include the AUTF, the Association of Freight Transport Users. More generally, there are two major professional organizations in France: the small business organization (CGPME), and the large business organization (MEDEF). The regulation of payment terms has always been on the agenda of the small business organization and never on the agenda of the large business organization.

${ }^{28}$ I obtain similar results when I scale the change in EBITDA by lagged EBITDA, or when I compute the covariance of the change in cash-flows to the change in aggregate cash-flows in my sample rather than real GDP growth.

${ }^{29}$ The sample is restricted to firms with more than two hundred euros in sales in 2003. A similar approach is adopted in Bertrand et al. (2007). This restriction does not affect the results.

${ }^{30}$ Given that some firms might default in 2003 and not report to the tax administration in that year, I use the latest balance sheet information to construct controls.

${ }^{31}$ Additionally, seasonality might affect the quality of receivables over sales as a proxy for payment terms. Suppose that prior to the reform, treated firms provided no trade credit in the first semester and large amounts of trade credit in the second semester. Then, suppose that following the reform, they adopted the opposite behavior. In this case, I might overestimate the impact of the reform. However, it is unlikely that the seasonality of firms in the sample changes dramatically after 2006.

${ }^{32}$ Throughout the paper, I use the terms bankruptcy or corporate default interchangeably.

${ }^{33}$ This rich dataset is also used in Boissay and Gropp (2013)

${ }^{34}$ The analysis relies on a linear model to avoid the issues highlighted in Ai and Norton (2003).

${ }^{35}$ Moreover, the results are unlikely to be driven by better opportunities in the treated and control sectors. Table AIII in the Internet Appendix, which compares the log aggregate sales and value added in the treated and control sectors before and after the restriction, shows no significant differences between the two.

${ }^{36}$ See Section III.B for the computation of the beta.

${ }^{37}$ See Section III.B for the computation of the beta.

${ }^{38}$ Smaller inventories are likely to lead to more frequent shortfalls, which amounts to a drop in product quality, as suggested in Matsa (2011a) and Matsa (2011b), for instance. 


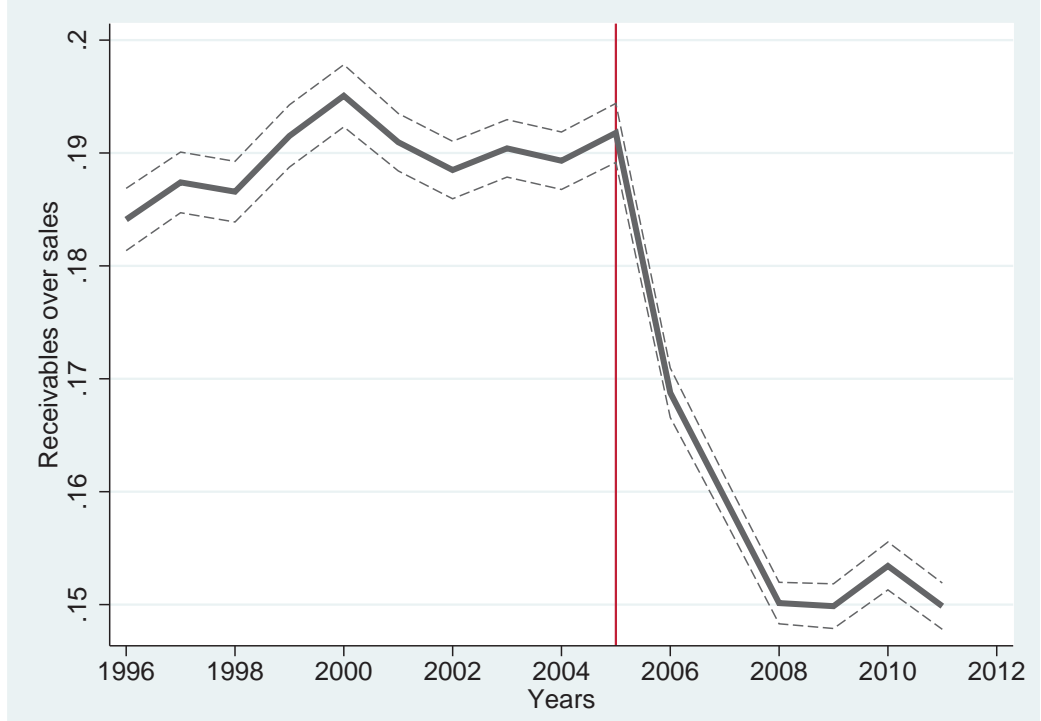

Figure I. Receivables over sales in the transportation sector in France, 1996-2011. This figure shows the historical payment terms, proxied by the ratio of receivables to sales in the transportation sector in France from 1996 to 2011. These series are produced by Banque de France, based on their proprietary database, FIBEN, which includes roughly one-third of the firms of the main sample used in this paper. Banque de France discloses their statistics at the two-digit sector level. Tucking firms account for approximately $70 \%$ of firms in the transportation sector. The dashed lines denote 1\% confidence intervals. The vertical line denotes the adoption of the trade credit regulation reform (2006). 


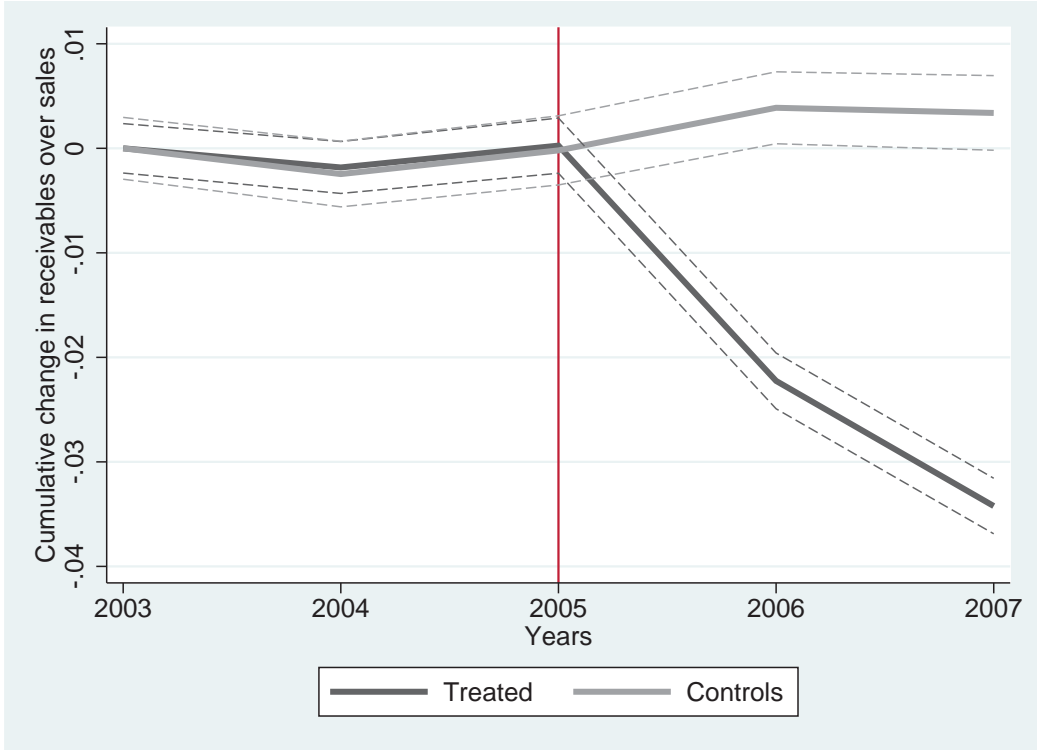

Figure II. Trends in payment terms among treated and control firms. This figure shows the average cumulative change in payment terms, proxied by the ratio of receivables to sales, around the trade credit regulation reform (2006) in the treated and control groups. The trucking industry is the treated group (15,987 firms). The control group includes the sectors closest to the trucking industry in terms of input and output and that are not using transportation services. The dashed lines denote $1 \%$ confidence intervals. The vertical line denotes the adoption of the trade credit regulation reform (2006). 
A. Cumulative change in average receivables over sales

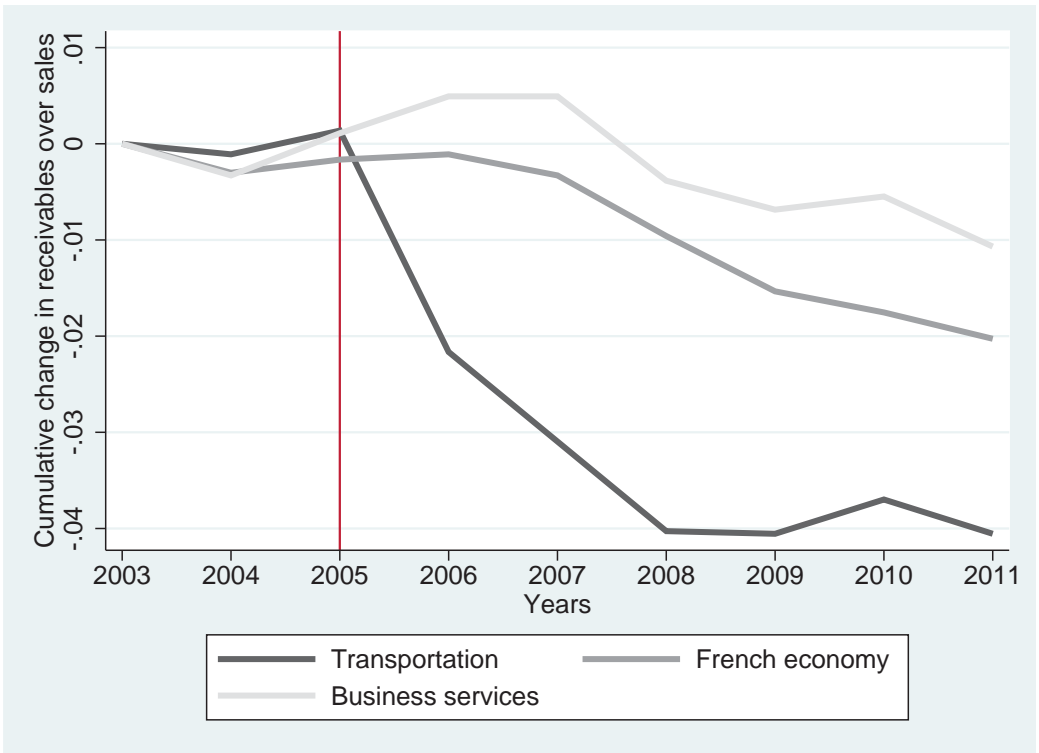

B. Cumulative change in the log nb. of defaults

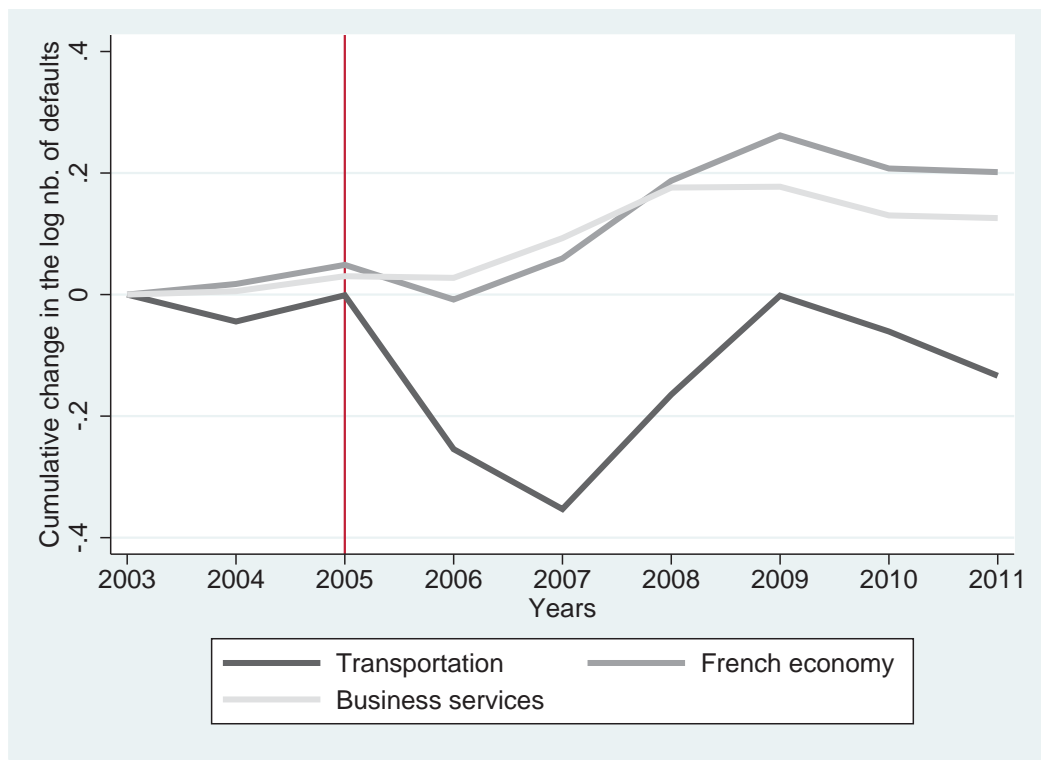

Figure III. Long-term impact of the trade credit regulation reform, 2003-2011. This figure shows the long-term effect of the trade credit regulation reform (2006) on payment terms and defaults (Panel B). Each panel contrasts the effects of the reform on the transportation sector with the evolution of payment terms and defaults in the rest of the French economy and on the business services sector, which serves as the main control group in the paper. Banque de France discloses their statistics at the two-digit sector level. Tucking firms account for approximately $70 \%$ of firms in the transportation sector. Panel A presents the cumulative change in mean receivables over sales. Panel B presents the cumulative change in the log number of defaults. The vertical line denotes the adoption of the trade credit regulation reform (2006). 
Table I

Treated and controls

This table presents the composition of the treatment and control groups. The trucking industry is the treated group (15,987 firms). To construct the control group, I use the 2003 input-output table of the French economy at the three-digit level and split the sample based on (i) the share of trucking services out of the total input of each sector, (ii) the distance between the vectors of output shares of each sector and the trucking sector, and (iii) the distance between the vectors of input shares of each sector and the trucking sector. I restrict the sample to sectors falling in the first tercile of (i) the share of trucking services, (ii) the distance between vectors of output shares, and (iii) the distance between vectors of output shares. The control group includes twenty-seven sectors.

\begin{tabular}{llccc}
\hline \hline \multirow{5}{*}{ Treated } & & & \\
& Sector (3-digit) & Nb. of firms (2003) & $\%$ & Cum. \% \\
\cline { 2 - 5 } & & & & \\
& Road transportation & 14,112 & $88 \%$ & $88 \%$ \\
& Organization of cargo transportation & 1,875 & $12 \%$ & $100 \%$ \\
& Total & 15,987 & & \\
& & & & \\
\hline \multirow{3}{*}{ Controls } & Business services & & & \\
& Electrical equipment & 14,373 & $84 \%$ & $84 \%$ \\
& Electric motors, generators, and transformers & 1,589 & $9 \%$ & $93 \%$ \\
& Machine tools & 663 & $4 \%$ & $97 \%$ \\
& Total & 482 & $3 \%$ & $100 \%$ \\
& & 17,107 & & \\
\hline \hline
\end{tabular}




\section{Table II \\ Summary Statistics}

This table presents the summary statistics prior to the trade credit regulation reform (2006) for the main variables used in the analysis. The trucking industry is the treated group (15,987 firms). The control group includes twenty-seven sectors that are closest to the trucking industry in terms of input and output and that are not using transportation services. Panel A presents firm-level statistics for the analysis of the effect of the trade credit reform (2006) on trucking firms. Panel B presents sector-level statistics on entry. Panel C presents firm-level statistics on new firms.

Panel A: Firm-level statistics (2003): incumbents

\begin{tabular}{lcccccccc}
\hline & \multicolumn{3}{c}{ Treated } & & \multicolumn{3}{c}{ Controls } \\
\cline { 2 - 4 } Receivables over sales & Obs. & Mean & Std. dev. & & Obs. & Mean & Std. dev. \\
Receivables over assets & 15020 & 0.225 & 0.114 & & 15980 & 0.216 & 0.148 \\
Cash holdings over assets & 15020 & 0.503 & 0.207 & & 15980 & 0.418 & 0.253 \\
Fixed assets over assets & 15020 & 0.140 & 0.158 & & 15980 & 0.192 & 0.206 \\
Gross profit margin & 15020 & 0.234 & 0.181 & & 15980 & 0.213 & 0.206 \\
Return on assets & 15020 & 0.063 & 0.117 & & 15980 & 0.074 & 0.175 \\
Default dummy & 15020 & 0.149 & 0.316 & & 15980 & 0.188 & 0.420 \\
\hline
\end{tabular}

Panel B: Sector-level statistics (2003)

\begin{tabular}{lcccccccc}
\hline & \multicolumn{3}{c}{ Treated } & & \multicolumn{3}{c}{ Controls } \\
\cline { 2 - 4 } \cline { 8 - 9 } & Obs. & Mean & Std. dev. & & Obs. & Mean & Std. dev. \\
Log monthly nb. of firms +1 & 72 & 2.76 & 1.50 & & 324 & 1.60 & 1.87 \\
Log monthly nb. of small firms +1 & 72 & 2.42 & 1.48 & & 324 & 1.47 & 1.84 \\
Log monthly nb. of medium firms +1 & 72 & 1.56 & 1.27 & & 324 & 0.66 & 1.04 \\
Log monthly nb. of large firms +1 & 72 & 0.99 & 0.99 & & 324 & 0.45 & 0.80 \\
\hline
\end{tabular}

Panel C: Firm-level statistics (2003): entrants

\begin{tabular}{lcccccccc}
\hline & \multicolumn{3}{c}{ Treated } & & \multicolumn{3}{c}{ Controls } \\
\cline { 2 - 4 } & Obs. & Mean & Std. dev. & & Obs. & Mean & Std. dev. \\
Sales per employee & 1393 & 89.411 & 106.375 & & 2460 & 73.794 & 96.456 \\
Value added per employee & 1393 & 31.612 & 24.454 & & 2460 & 29.856 & 31.836 \\
Gross profit per employee & 1393 & 7.568 & 15.941 & & 2460 & 5.459 & 21.762 \\
Default within one year & 1393 & 0.000 & 0.000 & & 2460 & 0.000 & 0.000 \\
Default within two years & 1393 & 0.024 & 0.154 & & 2460 & 0.015 & 0.120 \\
Default within three years & 1393 & 0.069 & 0.253 & & 2460 & 0.053 & 0.224 \\
\hline \hline
\end{tabular}


Table III

\section{Effect of the Trade Credit Reform (2006) on Payment Terms}

This table presents the DID estimates of the effect of the trade credit regulation reform (2006) on receivables over sales, which proxy for payment terms. Post is a dummy equal to one in the two years following the reform (2006 and 2007) and zero in the three years prior to the reform (2003, 2004, and 2005). The trucking industry is the treated group (15,987 firms). The control group includes twenty-seven sectors closest to the trucking industry in terms of input and output, and that are not using trucking services. Initial controls are measured in (or prior to) 2003 and include the ratios of gross profit to assets, fixed assets to assets, debt to assets, sales to assets, and the log of assets. Standard errors are corrected for clustering at the sector-level and presented in parentheses. $* * *$, **, and $*$ indicate significance at the 1,5 , and $10 \%$ levels, respectively.

\begin{tabular}{lcccc}
\hline \hline & \multicolumn{3}{c}{ Receivables over sales } \\
\cline { 2 - 4 } & \multicolumn{3}{c}{$-0.035^{* * *}$} \\
Post $\times$ Treated & $-0.033^{* * *}$ & & $(0.003)$ \\
Treated $\times$ Year $=t-1$ & $(0.003)$ & & -0.000 \\
& & -0.000 & $(0.001)$ \\
Treated $\times$ Year $=t$ & & $(0.001)$ & $-0.030^{* * *}$ \\
& & $-0.027^{* * *}$ & & $(0.002)$ \\
Treated $\times$ Year $>t$ & & $-0.002)$ & & $-0.041^{* * *}$ \\
& & $(0.003)$ & & $(0.004)$ \\
Post $\times$ Initial controls & No & No & Yes & Yes \\
Firm FE & Yes & Yes & Yes & Yes \\
Year FE & Yes & Yes & Yes & Yes \\
Observations & & & & 136855 \\
$R^{2}$ & 136855 & 136855 & 136855 & 0.783 \\
& 0.781 & 0.782 & 0.783 & \\
\hline \hline
\end{tabular}




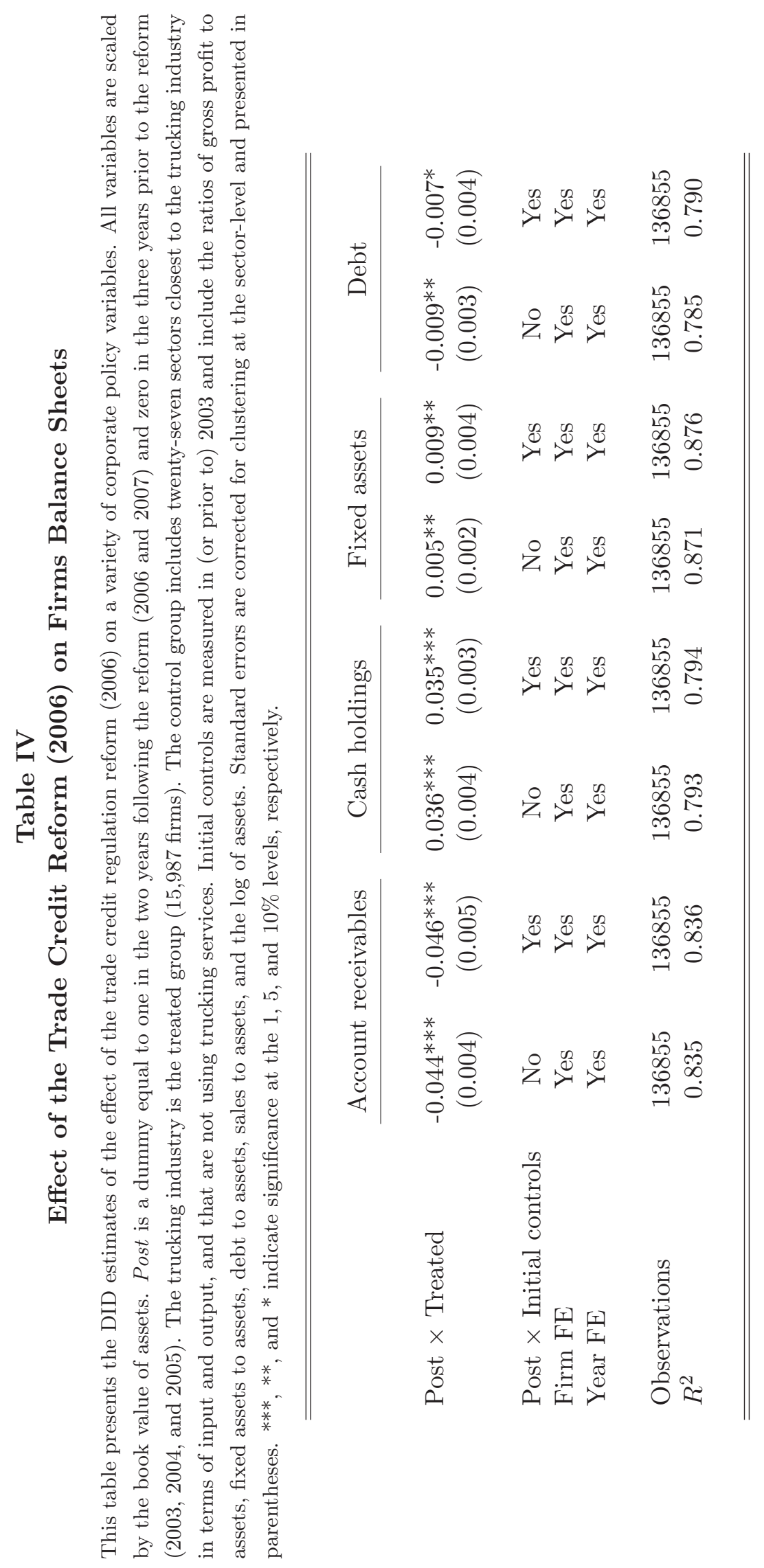




\section{Table V Effect of the Trade Credit Reform (2006) on Default}

This table presents the DID estimates of the effect of the trade credit regulation reform (2006) on corporate defaults. The dependent variable is a dummy equal to one in the year when a corporate default procedure is initiated, and zero before that. Post is a dummy equal to one in the three years following the reform (2006, 2007, and 2008) and zero in the three years prior to the reform (2003, 2004, and 2005). The trucking industry is the treated group (15,987 firms). The control group includes twenty-seven sectors closest to the trucking industry in terms of input and output, and that are not using trucking services. Initial controls are measured in (or prior to) 2003 and include the ratios of gross profit to assets, fixed assets to assets, debt to assets, sales to assets, and the log of assets. Standard errors are corrected for clustering at the sector-level and presented in parentheses. ${ }^{* * *},{ }^{* *}$, and $*$ indicate significance at the 1 , 5 , and $10 \%$ levels, respectively.

\begin{tabular}{|c|c|c|c|c|}
\hline \multirow[b]{2}{*}{ Post $\times$ Treated } & \multicolumn{4}{|c|}{ Corporate default dummy } \\
\hline & $\begin{array}{c}-0.007^{* * *} \\
(0.001)\end{array}$ & & $\begin{array}{c}-0.006^{* * *} \\
(0.002)\end{array}$ & \\
\hline Treated $\times$ Year $=t-1$ & & $\begin{array}{c}0.004 \\
(0.004)\end{array}$ & & $\begin{array}{c}0.004 \\
(0.004)\end{array}$ \\
\hline Treated $\times$ Year $=t$ & & $\begin{array}{l}-0.003 \\
(0.002)\end{array}$ & & $\begin{array}{l}-0.001 \\
(0.003)\end{array}$ \\
\hline Treated $\times$ Year $>t$ & & $\begin{array}{c}-0.008^{* * *} \\
(0.002)\end{array}$ & & $\begin{array}{c}-0.007^{* *} \\
(0.003)\end{array}$ \\
\hline Post $\times$ Initial controls & No & No & Yes & Yes \\
\hline Sector FE & Yes & Yes & Yes & Yes \\
\hline Year FE & Yes & Yes & Yes & Yes \\
\hline Observations & 172889 & 172889 & 172889 & 172889 \\
\hline$R^{2}$ & 0.008 & 0.008 & 0.033 & 0.033 \\
\hline
\end{tabular}




\section{Table VI}

\section{Effect of the Trade Credit Reform (2006) on Payment Defaults and Liquidations}

This table presents the DID estimates of the effect of the trade credit regulation reform (2006) on payment defaults and liquidations. In Panel A, the dependent variable is a dummy equal to one if the company misses a payment on one of its suppliers and zero otherwise. In Panel B, the dependent variable is a dummy equal to one in the year when a liquidation procedure is initiated, and zero before that. Post is a dummy equal to one in the three years following the reform (2006, 2007 and 2008) and zero in the three years prior to the reform (2003, 2004, and 2005). The trucking industry is the treated group (15,987 firms). The control group includes twenty-seven sectors closest to the trucking industry in terms of input and output, and that are not using trucking services. Initial controls are measured in (or prior to) 2003 and include the ratios of gross profit to assets, fixed assets to assets, debt to assets, sales to assets, and the $\log$ of assets. Standard errors are corrected for clustering at the sector-level and presented in parentheses. ***, $* *$, and $*$ indicate significance at the 1,5 , and $10 \%$ levels, respectively.

Panel A: Payment default dummy

\begin{tabular}{|c|c|c|c|c|}
\hline Post $\times$ Treated & $\begin{array}{c}-0.015^{* * *} \\
(0.002)\end{array}$ & & $\begin{array}{c}-0.013^{* * *} \\
(0.003)\end{array}$ & \\
\hline Treated $\times$ Year $=t-1$ & & $\begin{array}{c}0.001 \\
(0.002)\end{array}$ & & $\begin{array}{c}0.002 \\
(0.002)\end{array}$ \\
\hline Treated $\times$ Year $=t$ & & $\begin{array}{c}-0.008^{* * *} \\
(0.002)\end{array}$ & & $\begin{array}{c}-0.007^{* * *} \\
(0.002)\end{array}$ \\
\hline Treated $\times$ Year $>t$ & & $\begin{array}{c}-0.018^{* * *} \\
(0.004)\end{array}$ & & $\begin{array}{c}-0.015^{* * *} \\
(0.004)\end{array}$ \\
\hline Post $\times$ Initial controls & No & No & Yes & Yes \\
\hline Sector FE & Yes & Yes & Yes & Yes \\
\hline Year FE & Yes & Yes & Yes & Yes \\
\hline Observations & 172889 & 172889 & 172889 & 172889 \\
\hline$R^{2}$ & 0.013 & 0.013 & 0.034 & 0.034 \\
\hline
\end{tabular}

Panel B: Liquidation dummy

\begin{tabular}{|c|c|c|c|c|}
\hline Post $\times$ Treated & $\begin{array}{c}-0.007^{* * *} \\
(0.001)\end{array}$ & & $\begin{array}{c}-0.005^{* * *} \\
(0.002)\end{array}$ & \\
\hline Treated $\times$ Year $=t-1$ & & $\begin{array}{c}0.004 \\
(0.004)\end{array}$ & & $\begin{array}{c}0.005 \\
(0.004)\end{array}$ \\
\hline Treated $\times$ Year $=t$ & & $\begin{array}{l}-0.002 \\
(0.002)\end{array}$ & & $\begin{array}{l}-0.001 \\
(0.003)\end{array}$ \\
\hline Treated $\times$ Year $>t$ & & $\begin{array}{c}-0.007^{* * *} \\
(0.002)\end{array}$ & & $\begin{array}{c}-0.006^{* *} \\
(0.003)\end{array}$ \\
\hline Post $\times$ Initial controls & No & No & Yes & Yes \\
\hline Sector FE & Yes & Yes & Yes & Yes \\
\hline Year FE & Yes & Yes & Yes & Yes \\
\hline Observations & 17288950 & 172889 & 172889 & 172889 \\
\hline$R^{2}$ & 0.007 & 0.007 & 0.031 & 0.031 \\
\hline
\end{tabular}




\section{Table VII \\ Effect of the Trade Credit Reform (2006) on Defaults, Conditional on Financial Strength}

This table presents the DID estimates of the effect of the trade credit regulation reform (2006) on corporate defaults. The dependent variable is a dummy equal to one in the year when a corporate default procedure is initiated, and zero before that. Post is a dummy equal to one in the three years following the reform (2006, 2007, and 2008) and zero in the three years prior to the reform (2003, 2004, and 2005). The trucking industry is the treated group (15,987 firms). The control group includes twenty-seven sectors closest to the trucking industry in terms of input and output, and that are not using trucking services. Initial controls are measured in (or prior to) 2003 and include the ratios of gross profit to assets, fixed assets to assets, debt to assets, sales to assets, and the $\log$ of assets. FC and NonFC are two dummies measuring whether the firm's exposure to financial constraints is high or low. $F C(N o n F C)$ equals one for firms in the bottom (top) half of the 2003 sample distribution of (i) payout ratio, (ii) one minus the leverage ratio, (iii) cash holdings over assets, (iv) age, and (v) book value of assets, and zero otherwise. Standard errors are corrected for clustering at the sector-level and presented in parentheses. ${ }^{* * *},{ }^{* *}$, and * indicate significance at the 1 , 5 , and $10 \%$ levels, respectively.

\begin{tabular}{|c|c|c|c|c|c|}
\hline & \multicolumn{5}{|c|}{ Dependent variable: Corporate default dummy } \\
\hline & Payout & Leverage & Cash & Age & Size \\
\hline Post $\times$ Treated $\times F C$ & $\begin{array}{c}-0.008^{* * *} \\
(0.002)\end{array}$ & $\begin{array}{c}-0.014^{* * *} \\
(0.002)\end{array}$ & $\begin{array}{c}-0.012^{* * *} \\
(0.002)\end{array}$ & $\begin{array}{c}-0.009^{* * *} \\
(0.003)\end{array}$ & $\begin{array}{c}-0.008^{* * *} \\
(0.002)\end{array}$ \\
\hline Post $\times$ Treated $\times$ NonFC & $\begin{array}{c}0.001 \\
(0.002)\end{array}$ & $\begin{array}{c}0.002 \\
(0.002)\end{array}$ & $\begin{array}{l}-0.000 \\
(0.003)\end{array}$ & $\begin{array}{c}-0.003^{* *} \\
(0.002)\end{array}$ & $\begin{array}{c}-0.004^{* *} \\
(0.002)\end{array}$ \\
\hline Post $\times F C$ & $\begin{array}{l}0.004^{*} \\
(0.002)\end{array}$ & $\begin{array}{c}0.015^{* * *} \\
(0.006)\end{array}$ & $\begin{array}{c}0.002 \\
(0.002)\end{array}$ & $\begin{array}{c}-0.003^{*} \\
(0.002)\end{array}$ & $\begin{array}{c}0.004 \\
(0.002)\end{array}$ \\
\hline Treated $\times F C$ & $\begin{array}{l}0.011^{* *} \\
(0.005)\end{array}$ & $\begin{array}{c}0.019^{* * *} \\
(0.005)\end{array}$ & $\begin{array}{c}0.009^{* *} \\
(0.004)\end{array}$ & $\begin{array}{c}0.015^{* * *} \\
(0.004)\end{array}$ & $\begin{array}{l}0.010^{* *} \\
(0.005)\end{array}$ \\
\hline$F C$ & $\begin{array}{c}0.005 \\
(0.003)\end{array}$ & $\begin{array}{c}-0.007^{*} \\
(0.004)\end{array}$ & $\begin{array}{c}0.015^{* * *} \\
(0.003)\end{array}$ & $\begin{array}{c}0.012^{* * *} \\
(0.003)\end{array}$ & $\begin{array}{l}-0.001 \\
(0.003)\end{array}$ \\
\hline Post $\times$ Initial controls & Yes & Yes & Yes & Yes & Yes \\
\hline Sector FE & Yes & Yes & Yes & Yes & Yes \\
\hline Year FE & Yes & Yes & Yes & Yes & Yes \\
\hline $\begin{array}{l}\text { Observations } \\
R^{2}\end{array}$ & $\begin{array}{c}172889 \\
0.033\end{array}$ & $\begin{array}{c}172889 \\
0.033\end{array}$ & $\begin{array}{c}172889 \\
0.036\end{array}$ & $\begin{array}{c}172889 \\
0.036\end{array}$ & $\begin{array}{c}172889 \\
0.033\end{array}$ \\
\hline Difference $F C$ versus $N o n F C$ & $\begin{array}{c}-0.009^{* * *} \\
(0.001)\end{array}$ & $\begin{array}{c}-0.016^{* * *} \\
(0.004)\end{array}$ & $\begin{array}{c}-0.012^{* * *} \\
(0.003)\end{array}$ & $\begin{array}{c}-0.006^{* *} \\
(0.002)\end{array}$ & $\begin{array}{c}-0.005^{* * *} \\
(0.001)\end{array}$ \\
\hline
\end{tabular}




\section{Table VIII \\ Effect of the Trade Credit Reform (2006) on Profit Margins, Conditional on Financial Strength}

This table presents the DID estimates of the effect of the trade credit regulation reform (2006) on firms' profit margin, measured as the ratio of gross profit to sales. Post is a dummy equal to one in the two years following the reform (2006 and 2007) and zero in the three years prior to the reform (2003, 2004, and 2005). The trucking industry is the treated group (15,987 firms). The control group includes twenty-seven sectors closest to the trucking industry in terms of input and output, and that are not using trucking services. Initial controls are measured in (or prior to) 2003 and include the ratios of gross profit to assets, fixed assets to assets, debt to assets, sales to assets, and the $\log$ of assets. $F C$ and $N o n F C$ are two dummies measuring whether the firm's exposure to financial constraints is high or low. $F C$ (NonFC) equals one for firms in the bottom (top) half of the 2003 sample distribution of (i) payout ratio, (ii) one minus the leverage ratio, (iii) cash holdings over assets, (iv) age, and (v) book value of assets, and zero

otherwise. Standard errors are corrected for clustering at the sector-level and presented in parentheses. ***, **, and * indicate significance at the 1,5 , and $10 \%$ levels, respectively.

\begin{tabular}{lccccc}
\hline \hline & \multicolumn{5}{c}{ Dependent variable: Profit margin } \\
\cline { 2 - 6 } & Payout & Leverage & Cash & Age & Size \\
\hline \multirow{2}{*}{ Post $\times$ Treated $\times F C$} & -0.002 & -0.004 & -0.001 & -0.003 & -0.002 \\
& $(0.004)$ & $(0.004)$ & $(0.006)$ & $(0.003)$ & $(0.003)$ \\
Post $\times$ Treated $\times$ NonFC & -0.002 & 0.000 & -0.003 & -0.001 & -0.002 \\
& $(0.004)$ & $(0.004)$ & $(0.002)$ & $(0.005)$ & $(0.004)$ \\
Post $\times$ FC & -0.000 & 0.003 & 0.001 & $0.006 * *$ & -0.003 \\
& $(0.003)$ & $(0.003)$ & $(0.005)$ & $(0.002)$ & $(0.004)$ \\
Post $\times$ Initial controls & Yes & Yes & Yes & Yes & Yes \\
Firm FE & Yes & Yes & Yes & Yes & Yes \\
Year FE & Yes & Yes & Yes & Yes & Yes \\
Observations & & & & & \\
$R^{2}$ & 136855 & 136855 & 136855 & 136855 & 136855 \\
& 0.684 & 0.684 & 0.684 & 0.684 & 0.684 \\
\hline \multirow{2}{*}{ Difference FC versus NonFC } & 0.001 & -0.004 & 0.002 & -0.002 & 0.000 \\
& $(0.004)$ & $(0.003)$ & $(0.005)$ & $(0.003)$ & $(0.004)$ \\
\hline \hline & & & & & \\
\hline
\end{tabular}


Table IX

\section{Effect of the Trade Credit Reform (2006) on Return on Assets, Conditional on Financial Strength}

This table presents the DID estimates of the effect of the trade credit regulation reform (2006) on firms' return on assets, measured as the ratio of gross profit to the book value of assets. Post is a dummy equal to one in the two years following the reform (2006 and 2007) and zero in the three years prior to the reform (2003, 2004, and 2005). The trucking industry is the treated group (15,987 firms). The control group includes twenty-seven sectors closest to the trucking industry in terms of input and output, and that are not using trucking services. Initial controls are measured in (or prior to) 2003 and include the ratios of gross profit to assets, fixed assets to assets, debt to assets, sales to assets, and the $\log$ of assets. FC and NonFC are two dummies measuring whether the firm's exposure to financial constraints is high or low. $F C$ (NonFC) equals one for firms in the bottom (top) half of the 2003 sample distribution of (i) payout ratio, (ii) one minus the leverage ratio, (iii) cash holdings over assets, (iv) age, and (v) book value of assets, and zero otherwise. Standard errors are corrected for clustering at the sector-level and presented in parentheses. $* * *, * *$, and $*$ indicate significance at the 1,5 , and $10 \%$ levels, respectively.

\begin{tabular}{lccccc}
\hline \hline & \multicolumn{5}{c}{ Dependent variable: Return on assets } \\
\cline { 2 - 6 } & Payout & Leverage & Cash & Age & Size \\
\hline \multirow{2}{*}{ Post $\times$ Treated $\times F C$} & -0.002 & -0.001 & 0.000 & -0.003 & -0.002 \\
& $(0.006)$ & $(0.005)$ & $(0.007)$ & $(0.006)$ & $(0.008)$ \\
Post $\times$ Treated $\times$ NonFC & 0.001 & -0.002 & -0.003 & -0.003 & -0.002 \\
& $(0.007)$ & $(0.006)$ & $(0.004)$ & $(0.007)$ & $(0.005)$ \\
Post $\times F C$ & 0.005 & 0.011 & -0.003 & $0.020^{* *}$ & 0.002 \\
& $(0.006)$ & $(0.007)$ & $(0.005)$ & $(0.008)$ & $(0.005)$ \\
Post $\times$ Initial controls & Yes & Yes & Yes & Yes & Yes \\
Firm FE & Yes & Yes & Yes & Yes & Yes \\
Year FE & Yes & Yes & Yes & Yes & Yes \\
Observations & & & & & \\
$R^{2}$ & 134709 & 134709 & 134709 & 134709 & 134709 \\
& 0.676 & 0.676 & 0.676 & 0.676 & 0.676 \\
\hline \multirow{2}{*}{ Difference FC versus NonFC } & -0.003 & 0.001 & 0.003 & 0.001 & -0.000 \\
& $(0.007)$ & $(0.005)$ & $(0.005)$ & $(0.008)$ & $(0.008)$ \\
& & & & & \\
\hline \hline
\end{tabular}


Table X

\section{Effect of the Trade Credit Reform (2006) on Payment Terms, Conditional on Financial Strength}

This table presents the DID estimates of the effect of the trade credit regulation reform (2006) on the ratio of receivables over sales. Post is a dummy equal to one in the two years following the reform (2006 and 2007) and zero in the three years prior to the reform (2003, 2004, and 2005). The trucking industry is the treated group (15,987 firms). The control group includes twenty-seven sectors closest to the trucking industry in terms of input and output, and that are not using trucking services. Initial controls are measured in (or prior to) 2003 and include the ratios of gross profit to assets, fixed assets to assets, debt to assets, sales to assets, and the $\log$ of assets. FC and NonFC are two dummies measuring whether the firm's exposure to financial constraints is high or low. FC (NonFC) equals one for firms in the bottom (top) half of the 2003 sample distribution of (i) payout ratio, (ii) one minus the leverage ratio, (iii) cash holdings over assets, (iv) age, and (v) book value of assets, and zero otherwise. Standard errors are corrected for clustering at the sector-level and presented in parentheses. ***,**, and * indicate significance at the 1 , 5 , and $10 \%$ levels, respectively.

\begin{tabular}{lccccc}
\hline \hline & \multicolumn{5}{c}{ Dependent variable: Receivables over sales } \\
\cline { 2 - 6 } & Payout & Leverage & Cash & Age & Size \\
\hline \multirow{2}{*}{ Post $\times$ Treated $\times F C$} & $-0.034^{* * *}$ & $-0.034^{* * *}$ & $-0.029^{* * *}$ & $-0.032^{* * *}$ & $-0.030^{* * *}$ \\
& $(0.003)$ & $(0.003)$ & $(0.003)$ & $(0.002)$ & $(0.002)$ \\
Post $\times$ Treated $\times$ NonFC & $-0.039^{* * *}$ & $-0.036^{* * *}$ & $-0.040^{* * *}$ & $-0.037^{* * *}$ & $-0.040^{* * *}$ \\
& $(0.004)$ & $(0.003)$ & $(0.003)$ & $(0.004)$ & $(0.004)$ \\
Post $\times F C$ & $0.004^{*}$ & 0.003 & $0.013^{* * *}$ & -0.002 & 0.004 \\
& $(0.002)$ & $(0.002)$ & $(0.002)$ & $(0.003)$ & $(0.003)$ \\
Post $\times$ Initial controls & Yes & Yes & Yes & Yes & Yes \\
Firm FE & Yes & Yes & Yes & Yes & Yes \\
Year FE & Yes & Yes & Yes & Yes & Yes \\
Observations & & & & & 136855 \\
$R^{2}$ & 136855 & 136855 & 136855 & 136855 & 0.783 \\
& 0.783 & 0.783 & 0.783 & 0.783 & \\
\hline \multirow{2}{*}{ Difference FC versus NonFC } & $0.006^{*}$ & 0.003 & $0.011^{* * *}$ & $0.005^{*}$ & $0.010^{* * *}$ \\
& $(0.003)$ & $(0.003)$ & $(0.002)$ & $(0.003)$ & $(0.003)$ \\
\hline \hline & & & & & \\
\hline
\end{tabular}


Table XI

\section{Effect of the Trade Credit Reform (2006) on Trade Credit Defaults, Conditional on Financial Strength}

This table presents the DID estimates of the effect of the trade credit regulation reform (2006) on trade credit defaults (allowance for doubtful receivables over receivables). Post is a dummy equal to one in the two years following the reform (2006 and 2007) and zero in the three years prior to the reform (2003, 2004, and 2005). The trucking industry is the treated group (15,987 firms). The control group includes twenty-seven sectors closest to the trucking industry in terms of input and output, and that are not using trucking services. Initial controls are measured in (or prior to) 2003 and include the ratios of gross profit to assets, fixed assets to assets, debt to assets, sales to assets, and the $\log$ of assets. $F C$ and NonFC are two dummies measuring whether the firm's exposure to financial constraints is high or low. $F C(N o n F C)$ equals one for firms in the bottom (top) half of the 2003 sample distribution of (i) payout ratio, (ii) one minus the leverage ratio, (iii) cash holdings over assets, (iv) age, and (v) book value of assets, and zero

otherwise. Standard errors are corrected for clustering at the sector-level and presented in parentheses. ***, **, and * indicate significance at the 1,5 , and $10 \%$ levels, respectively.

\begin{tabular}{|c|c|c|c|c|c|}
\hline & \multicolumn{5}{|c|}{ Dependent variable: Share of doubtful receivables } \\
\hline & Payout & Leverage & Cash & Age & Size \\
\hline Post $\times$ Treated $\times F C$ & $\begin{array}{c}0.002^{* *} \\
(0.001)\end{array}$ & $\begin{array}{c}0.001 \\
(0.001)\end{array}$ & $\begin{array}{c}0.001 \\
(0.001)\end{array}$ & $\begin{array}{l}0.002^{*} \\
(0.001)\end{array}$ & $\begin{array}{c}0.001 \\
(0.001)\end{array}$ \\
\hline Post $\times$ Treated $\times$ NonFC & $\begin{array}{c}0.000 \\
(0.001)\end{array}$ & $\begin{array}{c}0.001 \\
(0.001)\end{array}$ & $\begin{array}{c}0.001^{* *} \\
(0.001)\end{array}$ & $\begin{array}{l}0.001^{*} \\
(0.001)\end{array}$ & $\begin{array}{c}0.002^{* * *} \\
(0.000)\end{array}$ \\
\hline Post $\times F C$ & $\begin{array}{c}0.000 \\
(0.001)\end{array}$ & $\begin{array}{l}-0.000 \\
(0.001)\end{array}$ & $\begin{array}{c}-0.002^{* *} \\
(0.001)\end{array}$ & $\begin{array}{c}-0.002^{* * *} \\
(0.001)\end{array}$ & $\begin{array}{c}0.000 \\
(0.001)\end{array}$ \\
\hline Post $\times$ Initial controls & Yes & Yes & Yes & Yes & Yes \\
\hline Firm FE & Yes & Yes & Yes & Yes & Yes \\
\hline Year FE & Yes & Yes & Yes & Yes & Yes \\
\hline $\begin{array}{l}\text { Observations } \\
R^{2}\end{array}$ & $\begin{array}{c}118182 \\
0.750\end{array}$ & $\begin{array}{c}118182 \\
0.750\end{array}$ & $\begin{array}{c}118182 \\
0.750\end{array}$ & $\begin{array}{c}118182 \\
0.750\end{array}$ & $\begin{array}{c}118182 \\
0.750\end{array}$ \\
\hline Difference $F C$ versus $N o n F C$ & $\begin{array}{c}0.002 \\
(0.001)\end{array}$ & $\begin{array}{c}0.000 \\
(0.001)\end{array}$ & $\begin{array}{l}-0.000 \\
(0.001)\end{array}$ & $\begin{array}{c}0.001 \\
(0.001)\end{array}$ & $\begin{array}{l}-0.001 \\
(0.001)\end{array}$ \\
\hline
\end{tabular}




\section{Table XII \\ Effect of the Trade Credit Reform (2006) on Entry}

This table presents the DID estimates of the effect of the trade credit regulation reform (2006) on the entry of new firms at the four-digit sector-level (33 sectors). The dependent variable is the log of the monthly number of new business creations plus one. I consider successively the entry of all firms, the entry of small (no employees at creation), medium (one or two employees at creation), and large firms (more than two employees at creation). Post is a dummy equal to one in the three years following the reform (2006, 2007, and 2008) and zero in the three years prior to the reform (2003, 2004, and 2005). The trucking sector is the treated group and includes six four-digit sectors. The control group includes twenty-seven four-digit sectors closest to the trucking industry in terms of input and output, and that are not using trucking services. Initial sector controls are measured in 2003 and include the average of the ratio of gross profit to assets, the ratio of fixed assets to assets, the ratio of debt to assets, the ratio of sales to assets, and the ratio of receivables to sales. Standard errors are corrected for clustering at the sector-level and presented in parentheses. $* * *, * *$, and $*$ indicate significance at the 1,5 , and $10 \%$ levels, respectively.

\begin{tabular}{|c|c|c|c|c|c|}
\hline & \multicolumn{5}{|c|}{ Dependent variable: Log monthly nb. of firm creations +1} \\
\hline & All firms & All firms & Small firms & Medium firms & Large firms \\
\hline Post $\times$ Treated & $\begin{array}{l}0.14^{* *} \\
(0.059)\end{array}$ & & $\begin{array}{c}0.18^{* * *} \\
(0.060)\end{array}$ & $\begin{array}{c}0.04 \\
(0.045)\end{array}$ & $\begin{array}{c}-0.04 \\
(0.042)\end{array}$ \\
\hline Treated $\times$ Year $=t-1$ & & $\begin{array}{c}-0.01 \\
(0.040)\end{array}$ & & & \\
\hline Treated $\times$ Year $=t$ & & $\begin{array}{c}-0.01 \\
(0.088)\end{array}$ & & & \\
\hline Treated $\times$ Year $>t$ & & $\begin{array}{l}0.21^{* *} \\
(0.095)\end{array}$ & & & \\
\hline Post $\times$ Initial sector controls & Yes & Yes & Yes & Yes & Yes \\
\hline Sector FE & Yes & Yes & Yes & Yes & Yes \\
\hline Month of the year FE & Yes & Yes & Yes & Yes & Yes \\
\hline Observations & 2376 & 2376 & 2376 & 2376 & 2376 \\
\hline$R^{2}$ & 0.960 & 0.961 & 0.961 & 0.935 & 0.896 \\
\hline
\end{tabular}




\section{Table XIII}

\section{Effect of the Trade Credit Reform (2006) on Entrants}

This table presents the DID estimates of the effect of the trade credit regulation reform (2006) on entrants. Panel A considers the probability that entrants experience a corporate default after business creation. Panel B considers various proxies for the efficiency of entrants, such as sales per employee, gross profit per employee, and value added per employee measured if the company files in the first or second year after creation. Post is a dummy equal to one if the firm was created in 2006 or 2007 and zero if it was created in 2003 or 2004. The trucking industry is the treated group. The control group includes twenty-seven sectors closest to the trucking industry in terms of input and output, and that are not using trucking services. Initial sector controls are measured in 2003 and include the average of the ratio of gross profit to assets, the ratio of fixed assets to assets, the ratio of debt to assets, the ratio of sales to assets, and the ratio of receivables to sales. Standard errors are corrected for clustering at the sector-level and presented in parentheses. $* * *, * *$, and $*$ indicate significance at the 1,5 , and $10 \%$ levels, respectively.

Panel A: Entrants' survival

\begin{tabular}{|c|c|c|c|}
\hline & $\begin{array}{c}\text { Default } \\
\text { within year } 1\end{array}$ & $\begin{array}{c}\text { Default } \\
\text { within year } 2\end{array}$ & $\begin{array}{c}\text { Default } \\
\text { within year } 3\end{array}$ \\
\hline Post $\times$ Treated & $\begin{array}{c}0.000 \\
(0.001)\end{array}$ & $\begin{array}{c}-0.016^{* * *} \\
(0.004)\end{array}$ & $\begin{array}{c}-0.018^{* * *} \\
(0.006)\end{array}$ \\
\hline Post $\times$ Initial sector controls & Yes & Yes & Yes \\
\hline Sector FE & Yes & Yes & Yes \\
\hline Cohort FE & Yes & Yes & Yes \\
\hline $\begin{array}{l}\text { Observations } \\
R^{2}\end{array}$ & $\begin{array}{c}66670 \\
0.001\end{array}$ & $\begin{array}{c}66670 \\
0.004\end{array}$ & $\begin{array}{c}66670 \\
0.013\end{array}$ \\
\hline \multicolumn{4}{|c|}{ Panel B: Entrants' efficiency } \\
\hline & $\begin{array}{c}\text { Sales } \\
\text { per employee }\end{array}$ & $\begin{array}{l}\text { Value added } \\
\text { per employee }\end{array}$ & $\begin{array}{l}\text { Gross profit } \\
\text { per employee }\end{array}$ \\
\hline Post $\times$ Treated & $\begin{array}{c}6.958 \\
(6.010)\end{array}$ & $\begin{array}{c}1.741 \\
(1.374)\end{array}$ & $\begin{array}{c}1.169 \\
(1.749)\end{array}$ \\
\hline Post $\times$ Initial sector controls & Yes & Yes & Yes \\
\hline Sector FE & Yes & Yes & Yes \\
\hline Cohort FE & Yes & Yes & Yes \\
\hline Year of filing FE & Yes & Yes & Yes \\
\hline Observations & 13761 & 13761 & 13761 \\
\hline$R^{2}$ & 0.143 & 0.068 & 0.015 \\
\hline
\end{tabular}

